\title{
4. Is France converging or not? The role of industrial relations
}

\section{Pierre Courtioux and Christine Erhel}

\section{INTRODUCTION}

The European Union (EU) exhibits substantial heterogeneity across the member states in terms of employment and social outcomes, as well as labour market and social protection institutions. This heterogeneity has been analysed in the literature about social protection regimes (Esping-Andersen 1990) and varieties of capitalism (Amable 2003). Institutional and policy diversity in the fields of employment and social protection is recognised by the EU in accordance with the subsidiary principle, although some common rules and goals have been adopted progressively throughout the construction of social Europe. In such a context social convergence in Europe remains a challenge, especially within the framework of low growth and persistent unemployment in many countries.

Several issues arise in relation to social convergence. First, analysing convergence requires a set of common indicators, which was recently renewed within the framework of the European Pillar of Social Rights (EPSR) adopted in November 2017. However, this set of indicators does not cover all the dimensions of social convergence and needs to be supplemented. Second, policy reforms have been numerous in Europe over the past ten years, and their consequences for social convergence are difficult to evaluate. Third, the role of industrial relations in these dynamics should not be underestimated: social dialogue and collective bargaining at different levels play an important role in the determination of wages and working and employment conditions (working time and types of contract), and may influence labour market inequalities (by gender, age and education level).

In this chapter we address these issues for the French case. After putting the EPSR in the context of EU social and employment policies, we construct a framework that enables us to identify France's particular features with regard to a large set of convergence indicators (based on an extension of the EPSR and consistent with the enlarged perspective developed in this book). We then examine the contribution of policy reforms and new trends in industrial relations to four specific policy areas, characterised by some convergence but with persistent gaps (employment of older workers, gender equality and labour market flexibilisation) or by continuing peculiarity (wage determination). The case study provides a specific focus on lifelong learning policies, which includes a comparative perspective on the heterogeneous national regimes in the EU, as well as an analysis of recent policy and institutional trends in France.

Regarding industrial relations, it is important to stress that France is in the course of implementing important reforms, which have been accelerated over the past two years 
with the so-called Loi Travail (Labour Law, 2016) ${ }^{1}$ and the recent Ordonnances Travail (Work Orders, September 2017). ${ }^{2}$ The main directions for reform are the decentralisation of collective bargaining (towards the firm level, although some important areas remain under sectoral competency) ${ }^{3}$ a change in the institutions for workers' representation at the firm level and in the rules for adopting agreements at the firm level (including some specific rules for small and very small businesses); and new rules for employment protection (economic and individual dismissals), generally providing more flexibility for firms. These reforms will have an impact on all the topics considered here, although these cannot be evaluated at this stage.

\section{SOCIAL AND EMPLOYMENT CONVERGENCE GOALS IN EUROPEAN POLICIES AND THE POSITION OF FRENCH SOCIAL ACTORS}

In the first decades of the European Community, social and employment convergence were considered mainly as secondary outcomes of economic and commercial integration. However, in the second half of the 1980s, as well as at the end of the 1990s, some policy initiatives were aimed at achieving better coordination and promoting common social goals at the European level. In the 1980s, this resulted from the development of European social dialogue, an increase in the budget of the structural funds, as well as the adoption of the European Charter of Fundamental Rights (1988). In 1997 the Amsterdam summit opened the way for the recognition of employment as a European policy goal, which was followed by the creation of the European Employment Strategy (EES) in 1998 and the wider Lisbon Strategy in 2000. In both cases the ambition was to promote social and employment convergence, which is supposed to be achieved through 'soft law' mechanisms. The open method of coordination (OMC), first applied to employment and then to retirement and social inclusion (see Box 4.1 for a chronology), is based on the determination of common goals (policy guidelines) and information exchanges between member states and the European Commission (through National Action Plans), as well as across countries (peer reviews, good practices and so on). Among the guidelines, some were quantified (such as the employment rates for 15-64-year-olds, women and older workers), while others expressed some general principles (such as activation and making work pay).

Following a change in government in most member states and EU enlargement in 2004, which increased the diversity of social protection systems and labour market regulations, these convergence policies started to weaken in the mid-2000s, a trend reinforced by the Great Recession. However, coordination ambitions have not disappeared, as shown by the Europe 2020 guidelines that still include targets for employment rates, social inclusion and education policies. In addition, some occasional initiatives were launched, such as the Youth Guarantee in 2013, aimed at developing youth-targeted labour market policy programmes in all member states and providing dedicated financing. The introduction of the EPSR in 2017 is also clearly an attempt to renew European coordination for social and employment issues. In terms of policy tools, it appears similar to the EES and OMC, as it relies on common general principles, as well as on indicators that make it possible to follow up on their implementation. 


\section{BOX 4.1 FROM THE LUXEMBOURG SUMMIT TO THE GOTHENBURG SUMMIT: 20 YEARS OF COMMON GOALS FOR SOCIAL AND EMPLOYMENT POLICIES IN EUROPE}

- November 1997: Luxembourg Summit and Amsterdam Treaty: employment as a goal for European policies. Launch of the European Employment Strategy (EES) and open method of coordination (OMC, Employment).

- March 2000: Lisbon Council: launch of the Lisbon Strategy; employment rate target for 2010 70 per cent for 15-64-year-olds and 60 per cent for women. OMC social inclusion.

- December 2000: Nice Council: job quality considered as a goal for EES.

- March 2001: Stockholm Council: employment rate target for older workers in 2010 should exceed 50 per cent for 55-64-year-olds. OMC pensions.

- December 2001: Laeken summit, common indicators on poverty, social exclusion and job quality.

- 2004: Report Jobs, Jobs, Jobs (Wim Kok, employment task force), priorities: reinforce adaptation capacities for both workers and firms, activation, human capital investment.

- 2005: Lisbon Strategy relaunch and EES revision; Integrated Guidelines for 2005-08.

- 2006 and 2007: Flexicurity expert group. Commission communication on Flexicurity.

- 2010: Europe 2020, new guidelines and indicators.

- 2011: Ad hoc group on job quality indicators.

- 2013: Social Investment Package (social policies and inclusion strategies - young people, unemployed).

- 2013: Youth Guarantee.

- September 2015: Announcement of the European Pillar of Social Rights (Juncker); consultation in 2016 and approval in 2017.

Historically, French governments have supported the initiatives launched in favour of social Europe or better coordination of labour market policies. This was especially the case when Jacques Delors was president of the European Commission (1985-95), but also between 1997 and 2011 (when France had a left-wing government under Lionel Jospin). More recently, the Youth Guarantee programme of 2013 was strongly supported by the French government (under President François Hollande). As far as the EPSR is concerned, the French government has sustained its implementation, even after the change of government in 2017: the new elected French President Emmanuel Macron was proactive at the Gothenburg summit and his speech stressed the need to achieve better social convergence. ${ }^{4} \mathrm{He}$ particularly underlined the role of directives (detached workers, for which a new compromise was achieved in October 2017), but also of structural funds, minimum wages, education and policies targeted at young people.

In terms of policy implementation, research on the impact of the EES and the OMC has generally shown some (limited) effects on the French labour market and social protection policies in the 2000s. These effects are obtained through the diffusion of ideas (for instance, activation, making work pay and flexicurity) and new processes (such as the National Action Plans) about labour market policies to policy-makers, administrations and social actors, as well as through leverage effects, such as the strategic use by some actors of some European goals in the national debate (Erhel and Palier 2005). However, despite this influence, some important limits on the efficiency of such policies have been highlighted: in particular, their implementation appears similar 
to an administrative process, involving a 'European elite' in the ministries, but with limited diffusion to politicians at various levels, the social partners, the media and public opinion (Barbier 2008).

In the case of the EPSR, it was well received by the trade unions, although in France both the Confédération générale du travail (General Confederation of Labour, CGT) and the Confédération française démocratique du travail (Democratic Confederation of Labour, CFDT) underline the need to enforce workers' rights beyond a declaration of general principles. For instance, the general secretary of the CFDT declared in Gothenburg: 'Nothing worse than a promise that is not honoured. The pillar must be now translated into real programmes for training, apprenticeship, youth employment, employment contracts and investment in the public sector. This will not happen without social dialogue, both at the European and member state level.' This citation is quoted in the presentation of the EPSR on the CFDT's website. ${ }^{5}$ Both the CFDT and the CGT adhere to the demands of the European Trade Union Confederation (especially minimum wages, high level of social protection, transferability of social rights across Europe, new rights for workers and social dialogue). ${ }^{6}$ However, as for most European policies, the attention devoted to the social pillar in the press and media has remained limited.

\section{THE SITUATION IN FRANCE WITH REGARD TO A LARGE SET OF SOCIAL CONVERGENCE INDICATORS}

In this section, following the general perspective adopted for this book, the situation of France is first analysed in terms of the European Social Pillar indicators. However, given that this list of indicators does not cover important dimensions of social convergence in Europe, some complementary indicators are introduced in the analysis. They aim at a better measurement of access to the labour market for various social groups, wages, working time, inequalities, education, training and lifelong learning, employment contracts and job quality, social protection and pensions. The detailed list is provided in the Appendix (Table 4.A1) to this chapter. In the next sub-section, a first step is aimed at positioning France with regard to other EU countries, using descriptive statistics and a typology of countries. A second step focuses on the dynamics over the past ten years and tries to identify the most important trends.

\subsection{Extending the Social Pillar: The Situation of France in a Typology of EU Countries in $\mathbf{2 0 1 5}$}

A first way to compare France with other EU countries and to identify its particular features is to compare an extended list of indicators to the European average. Appendix Table 4A.1 shows that France is generally in a more favourable situation than the EU average, especially with regard to wage levels, income inequalities, poverty rates and all variables related to social protection (activation policies, childcare, unemployment insurance and pension replacement rates, and unmet medical needs). However, this is not the case for labour market indicators, especially unemployment rates and youth unemployment indicators, but also temporary contracts and in-work accidents. 
In order to better deal with heterogeneity within Europe and capture French specificities in comparison with other countries, we have taken an approach based on principal component analysis (PCA) and hierarchical agglomerative clustering (HAC) (Box 4.2).

When looking at the results of the PCA analysis based on social pillar scoreboard

\section{BOX 4.2 METHODOLOGY FOR COMPARATIVE ANALYSIS}

This section uses principal component analysis (PCA) coupled with hierarchical agglomerative clustering (HAC) to define country clusters and analyse convergence. These methods of multivariate analysis combine an analysis of correlation between a set of variables (PCA) and a clustering of countries that are close in terms of the combination of these correlated variables. They have been widely used to compare national regimes of social protection or labour market regulation (see, for instance, Esping-Andersen 1990; Amable 2003).

In this section, three sets of variables are used to define the clusters; these are reported in Appendix Table 4A.2(a). Moreover, the optimal number of clusters that we retain here for each clustering is determined by a minimisation of intragroup variance and a maximisation of intergroup variance.

The first set of variables and the first clustering refers to the social pillar as defined by the benchmarking strategy of the European Commission (the social pillar 'scoreboard'). It is composed of 12 variables stemming from the European Commission website and it is used to define country clusters in 2015 (Table 4.1, column 1). The variables are as follows: early school leavers; gender employment gap; income quintile share ratio; people at risk of poverty or social exclusion; young people not in employment, education or training; employment rate; unemployment rate; participation in labour market activation policies; compensation of employees per hour worked; impact of social transfers (excluding pensions) on poverty reduction; children below 3 years of age in formal childcare; and self-reported unmet need for medical care.

However, the European Commission's definition of social pillar indicators is very restrictive and does not cover some dimensions, such as wages, labour market inequalities, education, training and lifelong learning, types of contract and social protection, which have been defined as important dimensions to be covered in studying convergence. In this view, we propose to extend the scope of the analysis with 12 additional variables. These variables produced by Eurostat and/or the OECD are comparable across countries. They are added to the first set of variables in order to test the robustness of the clusters and to provide a second clustering (Table 4.1, column 2). These additional variables are as follows: employment rate females 20-64 years of age, employment rate 55-64 years of age, youth unemployment rate 15-24 years of age, youth unemployment ratio 15-24 years of age, median earnings in euros (full-time, Standard de Pouvoir d'Achat - Purchasing Power Standard, SPA), low-wage earners as a proportion of all employees (excluding apprentices), participation rate in education and training (past four weeks) from 25 to 64 years of age, number of self-employed, temporary employees as a percentage of the total number of employees, average net replacement rates over 60 months of unemployment and net pension replacement rate for men (average wage level).

To address the issue of dynamics and convergence, it is also important to test the stability of clustering across time. In this view, using the same set of variables for 2005 and 2015, this section tests whether there are some changes in the composition of the clusters (third and fourth clustering). Owing to data availability constraints, we have to focus on a restricted set of variables that are available for both years (2005 and 2015): replacement rates for pensions and unemployment could not be introduced into the analysis.

Given data availability, it is possible to include 19 countries in the analysis (Austria, Belgium, Czech Republic, Germany, Denmark, Estonia, Finland, France, Hungary, Ireland, Luxembourg, Latvia, Netherlands, Norway, Poland, Portugal, Sweden, Slovakia and Slovenia). The United Kingdom and Spain cannot be included. 
Table 4.1 Country clusters for 2015, 19 countries

\begin{tabular}{|c|c|c|c|}
\hline \multicolumn{2}{|c|}{ Social pillar scoreboard variables } & \multicolumn{2}{|c|}{ Extended set of variables } \\
\hline \multirow[t]{7}{*}{ Cluster 1} & AT & AT & \multirow{7}{*}{ Cluster 1} \\
\hline & $\mathrm{DE}$ & DE & \\
\hline & DK & DK & \\
\hline & SE & SE & \\
\hline & NL & NL & \\
\hline & NO & NO & \\
\hline & LU & FI & \\
\hline \multirow[t]{3}{*}{ Cluster 2} & $\mathrm{EE}$ & $\mathrm{EE}$ & \multirow{2}{*}{ Cluster 2} \\
\hline & LV & LV & \\
\hline & PT & PT & \multirow{5}{*}{ Cluster 3} \\
\hline \multirow[t]{9}{*}{ Cluster 3} & $\mathrm{BE}$ & $\mathrm{BE}$ & \\
\hline & FR & FR & \\
\hline & IE & IE & \\
\hline & FI & LU & \\
\hline & $\mathrm{CZ}$ & $\mathrm{CZ}$ & \multirow{5}{*}{ Cluster 3} \\
\hline & $\mathrm{HU}$ & $\mathrm{HU}$ & \\
\hline & PL & PL & \\
\hline & SK & SK & \\
\hline & SV & SV & \\
\hline
\end{tabular}

Note: $\mathrm{AT}=$ Austria, $\mathrm{BE}=$ Belgium, $\mathrm{CZ}=$ Czech Republic, $\mathrm{DE}=$ Germany, $\mathrm{DK}=$ Denmark, $\mathrm{EE}=$

Estonia, FI $=$ Finland, FR $=$ France, $\mathrm{HU}=$ Hungary, $\mathrm{IE}=$ Ireland, $\mathrm{LU}=$ Luxembourg, $\mathrm{LV}=\mathrm{Latvia}, \mathrm{NL}=$ Netherlands, $\mathrm{NO}=$ Norway, $\mathrm{PL}=$ Poland, $\mathrm{PT}=$ Portugal, $\mathrm{SE}=$ Sweden, $\mathrm{SK}=$ Slovakia, $\mathrm{SV}=$ Slovenia.

Source: Eurostat, OECD; authors' calculation.

indicators (first set of variables), the variables that explain most of the heterogeneity across countries are the following: level of compensation per hours worked, impact of social transfers on poverty reduction, self-reported unmet need for medical care and level of inequality. This leads us to differentiate three groups of countries.

A first group is composed of seven Nordic and continental countries (Table 4.1) that are generally characterised by a better than average situation for all the indicators included in the analysis. The second cluster groups three countries (two Baltics and Portugal) showing intermediate performances in employment rate, gender employment gap, the share of young people not in employment, education or training (NEETs), but high poverty, low hourly wages, very limited participation in activation measures, and high unmet medical needs. A third group of nine continental and eastern countries (to which France belongs) is generally close to the average, with a gap in terms of women's and older workers' employment rates. 
France belongs to this last cluster, characterised by average performances in general. However, this group remains relatively large and heterogeneous. Within this group, France stands out because of its higher unemployment rate and higher share of NEETs. For the other indicators it is generally in a better position than the average of its cluster, and even closer to the Nordic cluster in some cases (poverty risk, compensation level, indicators related to social expenditures, activation and childcare).

When we add to the clustering some variables that describe other dimensions of social convergence in Europe (second set of variables, see Box 4.1 and Appendix Table 4A.1), this intermediate cluster splits, with first a group including France and other continental countries and second another group composed of eastern European countries (Table 4.1). These clusters differ mainly on compensation for hours worked, childcare and participation in labour market activation, which are more developed in the first group (cluster 3), whereas the unemployment rate, the share of early school leavers and NEETs are also higher than in the other group. Figures $4.1 \mathrm{a}$ and $4.1 \mathrm{~b}$ present the characteristics of the four clusters according to this enlarged set of convergence indicators.

When we consider the new variables introduced in this second step of comparative analysis, it is noticeable that France belongs to the cluster exhibiting the highest average youth unemployment rate, youth unemployment ratio and NEETs. More positively, this cluster also exhibits a higher replacement rate for unemployment, as well as the highest replacement rate of retirement pensions. The share of low wage workers is very limited. Notably, atypical employment (temporary contracts and part-time) stands at a relatively high level and participation in education and training is intermediate.

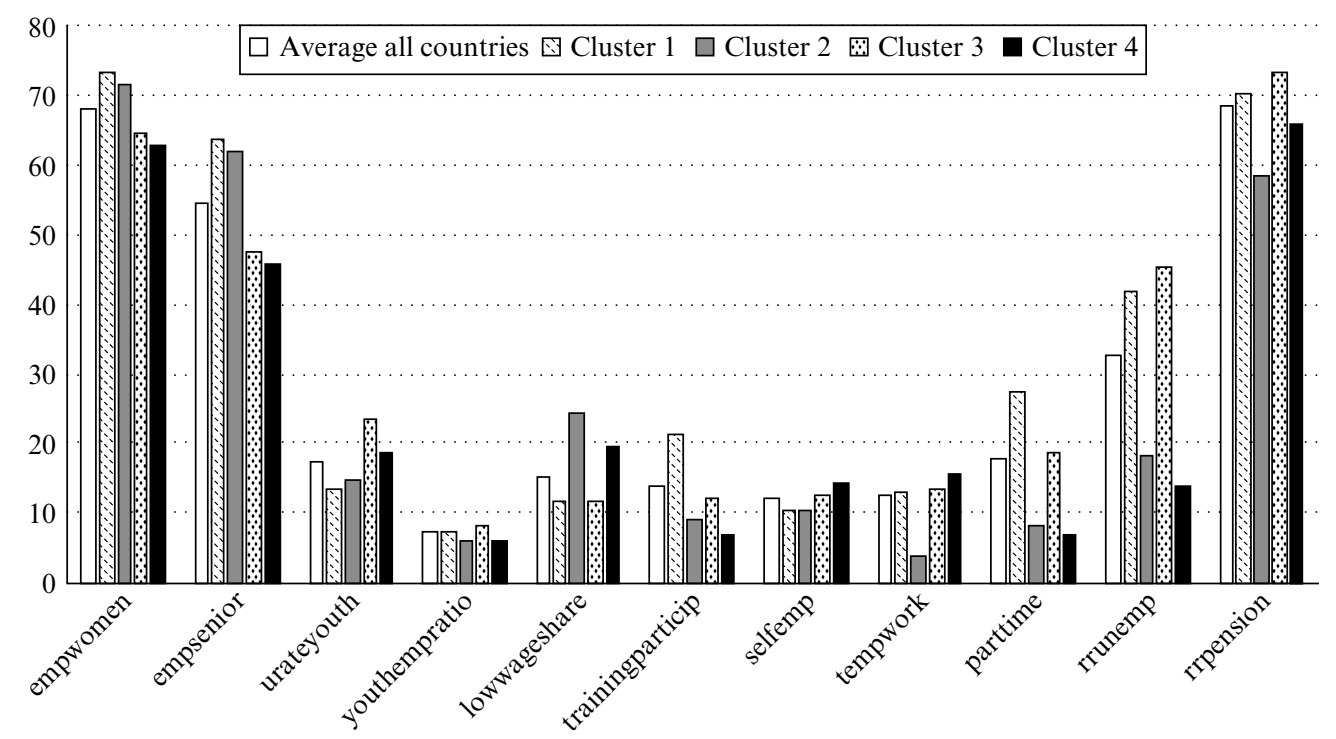

Source: See Appendix Table 4A.2a, authors' calculations.

Figure 4.1a Characteristics of the clusters in comparison with all-countries average (clustering 2): European Social Pillar indicators 


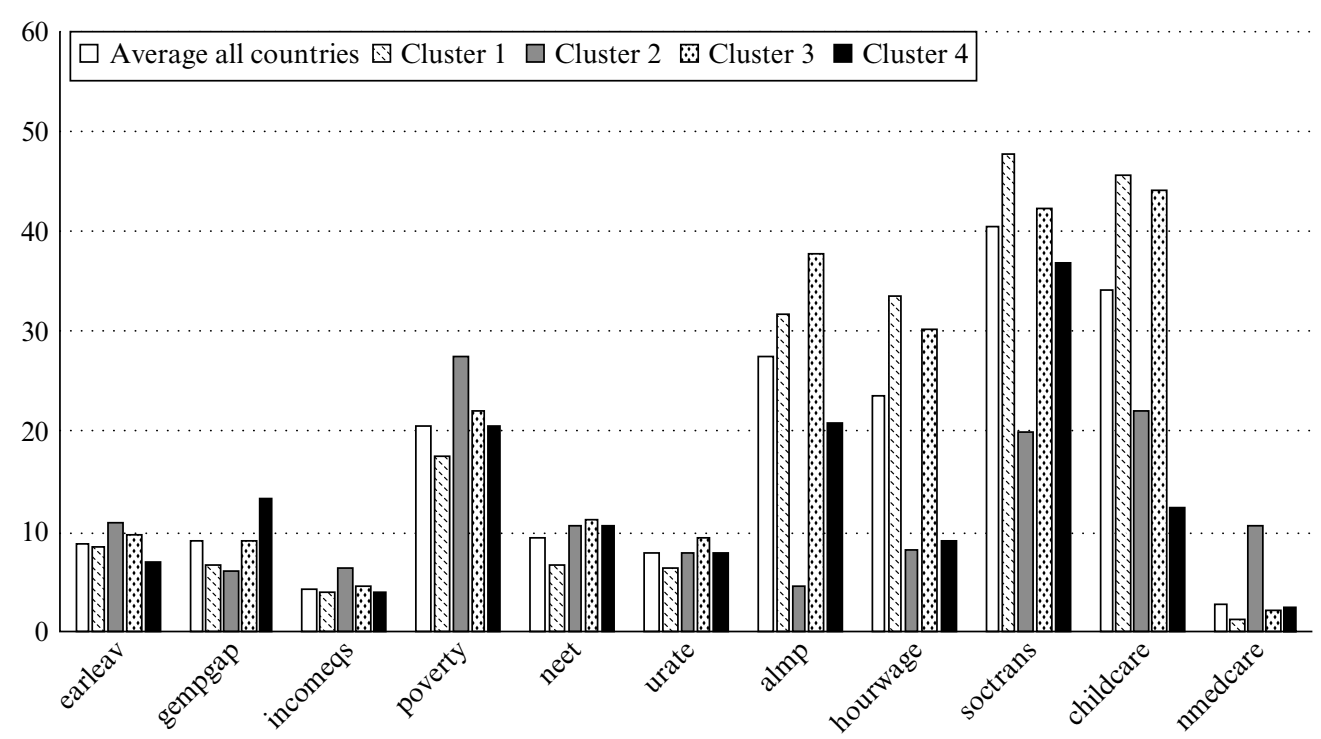

Source: See Appendix Table 4A.2a, authors' calculations.

Figure 4.1b Characteristics of the clusters in comparison with all-countries average (clustering 2): additional convergence indicators

To summarise, taking this extended view of the social pillar, France belongs to a group of countries finding it difficult to manage labour market inclusion in a context of high unemployment, especially for young people. However, in addition to high wages, this group tends to have a high level of social protection stemming directly from unemployment insurance, pensions and active labour market policies. Despite developed labour market flexibility (through temporary contracts, self-employment and so on), income inequalities remain relatively limited. In comparison with the cluster including the Nordic countries, some gaps also appear in terms of training participation or employment rates (global as well as for older workers and women).

\subsection{What Dynamics between 2005 and 2015?}

Another issue concerning social convergence is the identification of whether some countries or some groups of countries have become closer across time and the nature of the dynamics of the different indicators. It is possible to tackle this issue on the basis of a clustering done for a common set of variables available in 2005 and 2015 (see Box 4.1). The results are presented in Table 4.2. At the global level, heterogeneity between countries has decreased (see the reduction in the number of clusters from 4 to 3), which may reflect some convergence within the EU. France belongs to the second cluster, generally characterised by an intermediate situation with regard to most indicators in 2005 and remains in this group in 2015. However, the composition of the clusters has changed. The first cluster has been joined by Austria, Germany and Luxembourg, whereas the interme- 
Table 4.2 Country clusters across time, selected countries, 2005 and 2015

\begin{tabular}{|c|c|c|c|}
\hline \multicolumn{2}{|c|}{ Beginning of the period (2005) } & \multicolumn{2}{|c|}{ End of the period (2015) } \\
\hline \multirow[t]{5}{*}{ Cluster 1} & DK & DK & \multirow{8}{*}{ Cluster 1} \\
\hline & FI & FI & \\
\hline & NL & NL & \\
\hline & NO & $\mathrm{NO}$ & \\
\hline & $\mathrm{SE}$ & SE & \\
\hline \multirow[t]{7}{*}{ Cluster 2} & AT & AT & \\
\hline & $\mathrm{DE}$ & $\mathrm{DE}$ & \\
\hline & LU & LU & \\
\hline & $\mathrm{BE}$ & $\mathrm{BE}$ & \multirow{9}{*}{ Cluster 2} \\
\hline & FR & FR & \\
\hline & IE & IE & \\
\hline & SV & SV & \\
\hline \multirow[t]{4}{*}{ Cluster 3} & $\mathrm{CZ}$ & $\mathrm{CZ}$ & \\
\hline & $\mathrm{HU}$ & $\mathrm{HU}$ & \\
\hline & PL & PL & \\
\hline & SK & SK & \\
\hline \multirow[t]{3}{*}{ Cluster 4} & PL & PT & \\
\hline & SK & SK & \multirow{2}{*}{ Cluster 3} \\
\hline & SV & SV & \\
\hline
\end{tabular}

Note: $\mathrm{AT}=$ Austria, $\mathrm{BE}=$ Belgium, $\mathrm{CZ}=$ Czech Republic, $\mathrm{DE}=$ Germany, $\mathrm{DK}=$ Denmark, $\mathrm{FI}=$ Finland, $\mathrm{FR}=$ France, $\mathrm{HU}=$ Hungary, $\mathrm{IE}=$ Ireland, $\mathrm{LU}=$ Luxembourg, $\mathrm{NL}=$ Netherlands, $\mathrm{NO}=$ Norway, $\mathrm{PL}=$ Poland, $\mathrm{PT}=$ Portugal, $\mathrm{SE}=$ Sweden, $\mathrm{SK}=$ Slovakia, $\mathrm{SV}=$ Slovenia .

Source: Eurostat, authors' calculation.

diate group now includes some eastern or southern European countries (Czech Republic, Hungary, Poland, Slovakia and Portugal). Looking at the characteristics of the clusters, the relative situation of France seems to have deteriorated in terms of employment rate (global, as well as for women and older workers) and unemployment rate (especially for youth). These trends also explain why France remained in the intermediate group in 2015, rather than converging to the Nordic cluster as in the case of Germany where unemployment has been reduced over the period.

In this section we identified some areas in which France stand largely above the European average, such as the level of wages or the level of social protection, as well as some areas in which important gaps are observed, such as youth unemployment and social inclusion, but also older workers' and women's employment, despite some improvements over time for the latter two. We also showed that the trend towards higher 
flexibility that has been observed all over Europe also concerns the French labour market, risking a fall in job quality. In the next section will discuss the contribution of both policy reforms and trends in collective bargaining to these country features and dynamics. In the French case it is important to keep in mind that collective bargaining is a multi-level process, involving social dialogue (often tripartite) at the national level, and trade union and employers' organisations negotiations at both sectoral level and firm level. In addition, social dialogue and collective bargaining are strongly interrelated with policy reforms: on the one hand, some laws are based on previous tripartite agreements; on the other hand, new policy trends are often accompanied by some incentives or obligations for collective bargaining at the sector or firm level. We have selected four policy areas in which industrial relations have played a role in recent trends: older workers' employment and later retirement, gender equality on the labour market (section 4), wage determination and job quality (section 5). ${ }^{7}$

\section{TOWARDS HIGHER EMPLOYMENT RATES FOR OLDER PEOPLE AND WOMEN: THE CONTRIBUTION OF POLICY REFORMS AND COLLECTIVE BARGAINING}

European Union guidelines in the Lisbon Strategy and the EU2020 Strategy enshrined an increase in the employment rates of both older people and women, together with related goals, such as later retirement and gender equality. In the French case, policies and social dialogue have progressively integrated these goals, fostering some progress with regard to EU goals.

\subsection{Older Workers' Employment: From Social Consensus around Early Retirement to Employment Maintenance}

Until the beginning of the 2000s, there was a consensus in France in favour of early retirement (Courtioux and Erhel 2005). This consensus dates back to the 1970s and the beginning of the 1980s. Early retirement schemes were very popular among workers and therefore supported by trade unions (it was considered a deserved or opportunistic extension of retirement), but also among employers (it was considered to be a management tool for gently reducing the level of employment and/or for renewing the composition of the workforce in a context of recession and ageing). From a state perspective, early retirement schemes had the advantage of containing and even decreasing older workers' unemployment rate and were also seen as a means of promoting youth employment. In that context, early retirement schemes were also introduced in the unemployment insurance regime for unemployed workers aged 57 or over. Unemployed older workers were not only covered by relatively generous unemployment benefits, but also exempted from the obligation to search for a job (the measure was called Dispense de recherche d'emploi, or DRE), and therefore no longer considered to be unemployed in the labour market statistics. During the 1990s, the state withdrew from the early retirement consensus. Older people's inactivity before the age of 60 was seen as inappropriate in a context of pension funding problems. However, the early retirement consensus was still well established among the social partners: in 1995, after state ceased to fund such schemes, union and 
employer representatives agreed to launch an early retirement scheme financed by firms and unemployment insurance, which remained active until the early 2000s.

The new position of successive governments in favour of later retirement and higher older workers' employment rates, which was consistent with EU employment guidelines, has led to progressive changes in the 1990s and 2000s.

First, several pension reforms were implemented in 1993, 2003, 2008, 2010 and 2014. This set of adaptive reforms has built an institutional context of progressive changes concerning older workers' employment in France. This reform context may change in the coming years in so far as the new government has announced the launch of structural reforms for spring 2019.

The main results of these progressive reforms are as follows: an increase in the number of years of employment necessary to benefit from a full pension, ${ }^{8}$ as well as in the legal age for retirement; ${ }^{9}$ and the introduction of new calculation rules to keep down spending on pensions. These new rules also pursue the idea that older workers' employment rate should be raised by increasing the cost of retiring without a full career and by providing some incentives to stay at work after reaching the number of years corresponding to a full career. ${ }^{10}$ Consistently, general early retirement schemes have been abolished (including the DRE in 2009).

However, throughout these reforms, the idea has emerged that some compensation mechanisms should be introduced for those who had experienced hard working conditions or started to work early (Caser and Jolivet 2014). This idea was strongly supported by the trade unions and was a topic of social dialogue between 2003 and 2017. Following that logic, some specific early retirement programmes were introduced for workers with bad health resulting from exposure to dangerous or painful working conditions. ${ }^{11}$ Moreover, a specific early retirement scheme (Retraite anticipée pour carrière longue, RACL) was introduced for workers who started to work very early and were therefore entitled to retire before the legal age. ${ }^{12}$

In the same vein, to generalise the compensation principle in the face of substantial inequalities in life expectancy at retirement age, the trade unions promoted the creation of an individual account for arduous work (C3P, ${ }^{13}$ introduced in 2014) that generalised the compensation principle for hard working conditions during the working career. The account included various forms of compensation for workers enduring hard working conditions (working time reduction, training and early retirement) and it was financed through a specific contribution paid by firms. Workers' rights became transferable even if the worker changes job for a new firm or a new sector. The law called for collective bargaining at the sectoral level to define the precise conditions of arduous work, but it was considered too ambitious and difficult to implement. In September 2017 the arduous work account was simplified and firms' financial contribution was cancelled. ${ }^{14}$

Several laws and measures have been introduced to favour collective bargaining on older workers' employment, especially at the firm level. Such collective bargaining was supposed to include arduous work and its compensation, but also measures to promote seniors' employment at the firm level. The 2003 reform made it mandatory to negotiate on arduous work, but the definition of arduousness was not produced by law. To complement pension reforms, social partners were supposed to negotiate at three levels: at national level on the definition of arduousness, at the sectoral level on the promotion of older workers' employment, and at the firm level on older workers' employment 
and their access to training every three years. Despite trade unions being in favour of collective bargaining on these issues, the number of agreements remained very limited, as employers generally criticised the complexity of the process. To promote the signing of agreements at the firm level, the government introduced financial incentives in 2008 to reach agreement on quantitative objectives for older people's employment and on programmes favouring it (plan senior). The incentive was a penalty (corresponding to 1 per cent of the wage bill) until an agreement is signed. The result was a rapid increase in the number of agreements signed, but it seems that the quality of the negotiation process and the quality of the plans were very heterogeneous and very difficult to evaluate for researchers, as well as for the French employment administration (Claisse et al. 2011; Jolivet 2011).

An attempt to link older workers' employment, youth employment and knowledge transmission was also made, but was not successful. The Generation Contract, which was launched in 2013, could open access to state subsidies for firms hiring youth and maintaining older workers' employment at the same time (Jolivet and Thébault 2014).

Thus, the 1980s consensus around early retirement has progressively evolved towards a goal of higher older workers' employment, including some compensation mechanisms for disadvantaged older workers (long careers and hard working conditions), which were strongly supported by trade unions. Both individual incentives through the pension system and incentives to introduce employment plans at the firm level through collective bargaining have helped to increase older workers' employment. However, some challenges remain, especially to promote preventive intervention through training and easier working conditions or promotion of better health at work.

\subsection{Women's Employment and Gender Equality}

The French social model is supportive of women's employment, with a developed and subsidised childcare system. Childcare and family policies are financed by a tripartite body involving trade unions and employers' representatives in its board of directors (Caisse Nationale des Allocations Familiales). The presidency of this board is allotted to a member of the Confédération Française des Travailleurs Chrétiens (CFTC), which is one of the representative trade unions, with a Christian tradition and adopting a reformist position. Therefore, even if the state takes the lead in the definition and evolution of policies, social partners are directly involved in the management and funding of childcare and family policies.

In general, France has evolved towards a dual-earner model with a relatively low gender gap in employment between men and women. However, despite these positive changes, gender equality is far from being achieved. More specifically, the employment gap is linked to a life-course effect differentiated for men and women. The lone persons employment rate is more or less equivalent for men and women, but there is a gender gap in favour of men when they live in a couple. The family situations with the widest gap between men and women are those with at least one very young child (under 3 years of age) and families with three children or more. The main explanation of these persisting differences is the gender differences in the time dedicated to childcare and education (Lemière 2013) and their negative cumulative effects in a career perspective. However, female employment rates in France have reached the Lisbon target and there has been 
important progress in the situation of mothers with two children, whose employment rate has risen to that of women without children (Minni and Moschion 2010).

Another persisting inequality between men and women in employment concerns working time. Women are in part-time jobs more often than men are. This part-time work is largely involuntary: it is not specifically linked to the observed gender division of time allocated to childcare and education. In this view, the unemployment rate gender gap is not a good indicator of gender inequality on the labour market (Lemière 2013); more generally, women are more often at the margin of unemployment than men are; that is, they are not in a situation corresponding to the International Labour Organization (ILO) international definition of unemployment, but they are underemployed and looking for another job with various degrees of intensity, depending on the state of the labour market. This situation concerns mainly less educated women.

French family-orientated policies have helped to reduce the employment gap between men and women, but this has not progressed at the same pace for all women and inequalities are still important, especially by educational level. The development of private childcare (nannies) in the 1990s and 2000s has mainly benefited higher-income families and the best educated women, whereas the extension of parental leave to the second and then first child ${ }^{15}$ has mainly affected lower educated women, with perhaps a potential negative effect on their careers.

However, a recent reform (in 2014) of parental leave provides incentives to reduce women's period of inactivity ${ }^{16}$ and to share the leave between men and women. In addition to lower labour market participation for lower qualified mothers, or mothers of two or three children, the French labour market exhibits persistent wage inequalities between men and women, as well as differences in participation in management and boards of directors, and in politics. As regards wages, the gender gap for hourly net wages was 16.3 per cent in 2015, and 10 per cent remains unexplained after taking into account occupational and industry structure and the main individual characteristics. This gap increases with occupational group (it is highest for managers and professionals) and with wage level (Chamki and Toutlemonde 2015).

Several policies have been developed recently to reduce these gender inequalities, which have been supported by the trade unions. First, the law has progressively imposed parity in the lists presented by political parties and quotas have been introduced for all governance bodies in the private and public sector (40 per cent for boards of directors, nominations to higher positions in public administration and examination boards ${ }^{17}$ ). Second, specific guidelines for collective bargaining have been implemented in order to favour gender equality within firms, and especially wage equality. ${ }^{18}$ Firm-level collective bargaining about wages, gender equality and quality of working life is compulsory every four years (at least) in all firms where union delegates are present. In the absence of an agreement, the employer has to develop an action plan for gender equality. For firms with over 50 employees, the absence of an agreement or action plan may result in them being prevented from applying for public contracts or in the imposition of a financial penalty. The employer also has to provide to the works council or to workers' representatives detailed information about gender differences in the firm: the database has to include information about recruitment, access to training, working conditions, wages and promotions. At the sectoral level, several laws have also reinforced the obligation to include gender equality in collective bargaining and to develop information about differences 
between men and women, resulting in an increase in the number of agreements dealing with gender issues: in 2016, 135 sectoral agreements (13.4 per cent of the total) dealt with gender equality, a proportion that has remained almost stable since 2011 . Owing to the extension procedure, the Ministry of Labour can control the legality of these agreements and the coverage of these agreements is high. In terms of content, the latest report on collective bargaining in 2016 mentions some improvement in these agreements, as some of them include concrete measures to promote gender equality (concerning recruitment, training, working hours and work family reconciliation), but also some limitations related to the monitoring of progress and to the specific issue of wages for which specific and tangible measures are often missing (DGT 2017). However, the current position of the Ministry of Labour is to develop further collective bargaining on this issue and to provide employers with examples of good practice for gender equality. ${ }^{19}$

As far as trade unions are concerned, some of them have been promoting gender equality inside their organisations for many years: the CFDT established quotas in its executive council (the proportion of women among the union leadership is supposed to be at least as high as their share of the union membership, one-third at that time and 47 per cent now) as soon as 1982, and the CGT imposed gender parity in 1999 (the proportion of women members was 37 per cent in 2014). However, this is not the case with other representative trade unions, and the target of 40 per cent of women in the executive councils of any social institution (introduced in 2008) is far from being reached. In addition, the number of women among trade union leaders has remained limited, with two noticeable exceptions: Nicole Notat for CFDT (1992-2002) and Carole Couvert for CFE-CGC (2013-16). There are several reasons for this; some are related to the gender composition of trade unions (some include only a minority of women), others to a lack of awareness of gender issues. Gender segregation in employment can also play a role: women are overrepresented in the service sector where unionisation is low and employment precariousness very high, which may limit their involvement in unions and, more generally, in workers' representation and social dialogue. In such a context, quotas are not enough to promote women's participation in trade unions and social dialogue; they need to be accompanied by real protection and training to help women participate more actively (Guillaume et al. 2015).

\section{WAGE AND JOB QUALITY TRENDS: SOME FEATURES INFLUENCED BY INDUSTRIAL RELATIONS}

In the EU, France stands out for its relatively high wages - which have continued to grow since the financial and economic crisis - and for its fairly strict regulation of labour contracts. These characteristics are strongly linked with the traditional model of labour market institutions and industrial relations. However, this model has undergone significant reforms, favouring some convergence towards a more flexible labour market.

\subsection{Wage Trends in France: Disconnected from Productivity?}

Wage setting in France results from a three-level process, involving the state at the national level and the social partners at the industry and firm levels. 
At the national level, the minimum wage is determined according to an automatic rule based on inflation and the average wage of manual workers. Since 2010, the increase in the minimum wage takes place annually on 1 January (except if inflation exceeds 2 per cent, in which case additional adjustments may take place during the year). The government can decide additional increases (coups de pouce) on top of the automatic rule to increase the minimum wage: the last coup de pouce dates back to 2012. Since 2008, an experts' group advises the government and the National Commission for Social Dialogue (Commission Nationale de la Négociation Collective, CNNC). In contrast to other European countries, the experts' group does not involve any representative of the social partners, only academics and members of the economic administration. Since its creation, it has never recommended any increase over the automatic rule, and has recently criticised the indexation of the minimum wage on the manual workers' average wage. ${ }^{20}$

Industry-level bargaining, involving trade unions and employers' organisations, determines wage floors for different occupations and educational levels. Until 2017, the industry level was also pre-eminent in determining other components of workers' income, such as the thirteenth-month premium, the seniority premium, the quality or productivity premium and dismissal allowances. Annual negotiation is compulsory, but does not necessarily result in a new wage agreement (in which case the older wage agreement applies). The validity of industry-level wage agreements is based on representativeness of the social partners ${ }^{21}$ (they must represent at least 8 per cent of the votes in the staff elections for trade unions and 8 per cent of the companies for employers' organisations). However, the importance of wage agreements in the wage-setting process is also related to the fact that most agreements are extended by the Ministry of Labour to the whole industry, resulting in a very high coverage rate by industry-level agreements. On average, between 2003 and 2015, 400 wage agreements were extended annually. According to the recent labour ordinances of September 2017, the determination of wage floors remains the exclusive competence of industry-level collective bargaining, and the extension procedure is maintained. However, according to the ordinances, the industry level no longer has pre-eminence over the firm level as far as individual wages and income are concerned.

Since 1982, there has been an obligation to bargain annually on wages once a firm has union delegates. Firm-level agreements have to respect the minimum wage and industry wage floors, but their importance has been increased by 2017 ordinances according to which they can deviate from industry-level agreements for other elements of wages and income (such as premiums, see above).

The recent trend of real wages in France (see Figure 4.2) shows continued growth after the recession (between 2008 and 2011), a slight decrease in 2012 and more growth between 2013 and 2015 (in a period of low inflation, under 1 per cent). From the point of view of workers (and trade unions) these trends may be interpreted as a positive outcome of wage determination mechanisms (and collective bargaining institutions), as the result has been growing real compensation for employees over the period 2005-15 (Piasna 2017). However, during the crisis and in recent years (2014-15) wage growth has exceeded productivity growth, despite high unemployment. Such trends, which are relatively atypical in comparison with other Organisation for Economic Co-operation and Development (OECD) or European countries, have led economists to explore hypotheses based on wage rigidity. At the institutional level, both the minimum-wage and industrylevel agreements may contribute to these dynamics. However, minimum wage increases 


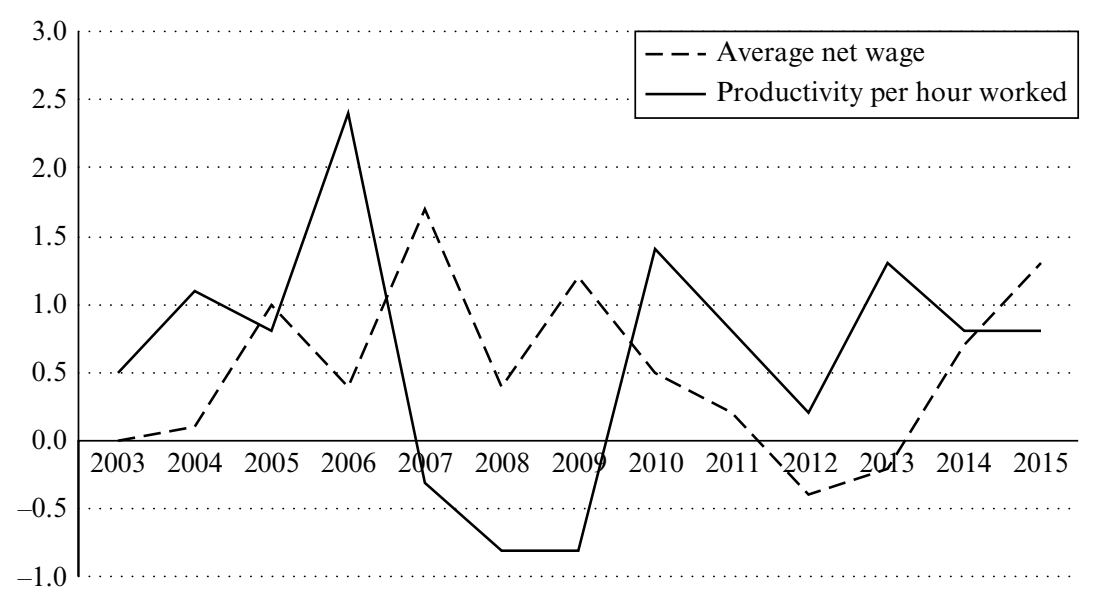

Source: DADS, INSEE (wages); Eurostat (productivity).

Figure 4.2 Annual growth of hourly productivity and real wages, France, 2003-2015 (constant euros)

have been limited since the crisis, remaining very close to inflation, which has decreased. In addition, the annual growth rate of industry-level wage floors has decreased over the period, reflecting some moderation in wage negotiations: it increased annually on average by 2 per cent between 2007 and 2009, 1.5 per cent between 2010 and 2013 and 1 per cent during 2014-16 (Gautier 2017). At the micro (firm) level, motivational factors may play an important role. In a context of low inflation, wage moderation implies limiting rises in nominal wages (or, even, decreasing their flexible part), which may discourage workers and reduce their efforts. According to employers' surveys, a majority (at workplaces with ten employees or more) consider that wage trends are part of a strategy to maintain a good social climate (Askénazy et al. 2013).

Given the importance of the industry level in wage determination, the influence of industry wage agreements on actual wages paid to employees has been questioned by some empirical analyses. Gautier recently (2017) showed that the impact of industry-level wage floors, even if generally significant, appears relatively small: over the period 2007 to 2016 he estimates the elasticity of wages to industry wage floors at 0.15 . That elasticity varies across industries and occupations; it is lower for managers and professionals than for other occupational groups, and it ranges from over 0.45 (for example, for manufacturing and construction) to less than 0.04 or non-significant (mostly in services). Other factors also play a significant role in individual wage dynamics, especially minimum wage variations and unemployment. In the case of unemployment, the elasticity is negative, but very small, indicating a low sensitivity of wage setting to labour market conditions.

Despite some apparent moderation in industry agreements in recent years, and their limited impact on observed wages, according to some empirical analyses, the current policy debate is still focused on the disconnection between wage and productivity trends after the crisis. Several economists have recommended opt-out clauses in industry collective agreements (for instance, for firms facing temporary drops in demand for their 
products or new entrants, see Askénazy et al. 2013), or ending the almost automatic extension of industry wage agreements. ${ }^{22}$

Following September 2017 ordinances, an experts' commission was created in 2018 to examine the economic consequences of the extension of sectoral agreements. In December 2017, the minimum wage experts' group also made some recommendations in order to moderate annual minimum wage increases by changing indexation rules (to be based on inflation rather than manual workers' wages). Such changes in the wage determination process would risk increasing the level of wage inequalities, which have been contained in France over the past 20 years. Although trade unions opposed such reforms, the issue of wage determination will probably be on the policy agenda in the coming years.

\subsection{Labour Market Flexibilisation and Job Quality Concerns}

France is usually characterised as a country with relatively high labour market regulation. According to the OECD's employment protection legislation (EPL) index, it belongs to a group of continental and southern European countries in which EPL for permanent and temporary contracts is over the OECD average. In addition, the French EPL index has not changed much over time. However, that stability does not reflect the trends observed on the French labour market, which has undergone many reforms and changes in employers' practices, resulting in higher actual flexibility (Askénazy and Erhel 2016).

The first notable trend concerns atypical employment, mainly temporary employment but also self-employment and part-time jobs (Figure 4.3). As far as temporary employment is concerned, its increase dates back to the 1980s and 1990s, following several legal reforms concerning the use of fixed-term contracts and temporary agency work. As a result, the share of temporary employment in France was over the European average

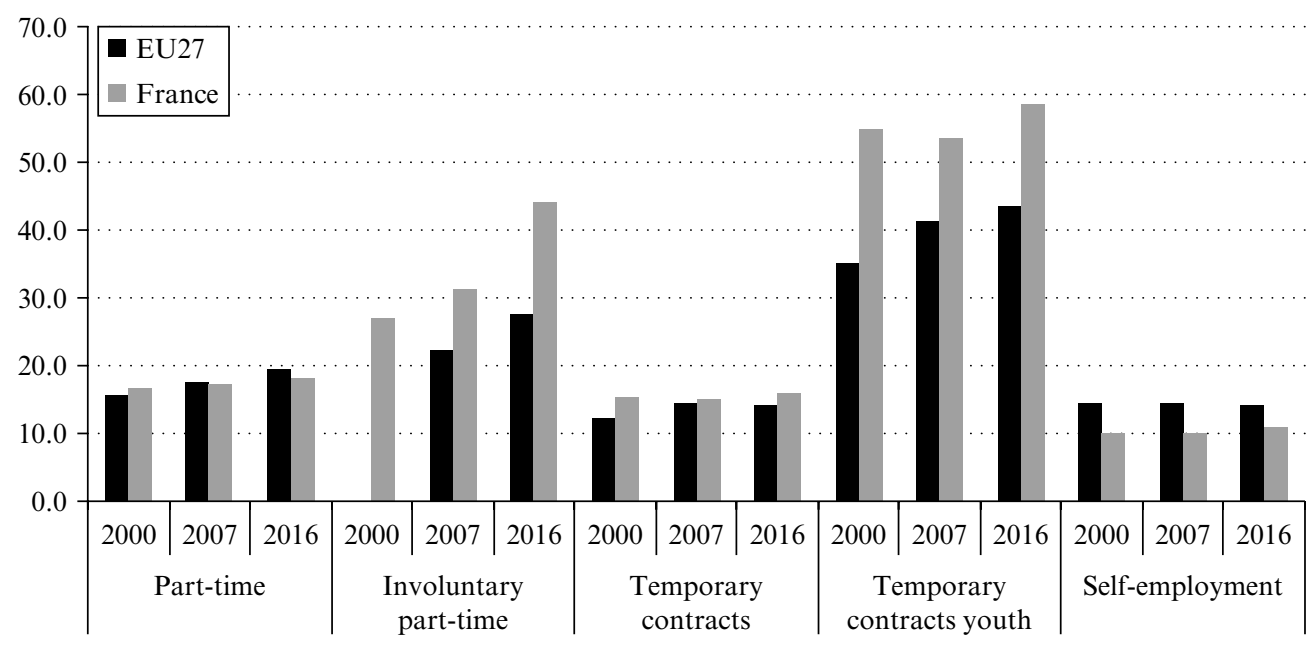

Source: Eurostat, Labour Force Survey (LFS), authors' calculation.

Figure 4.3 Atypical employment as a share of employment, France, 2000-2016 (\%) 
in 2000 (15.4 per cent in France against 12.2 per cent in the EU 27). After a period of stability from 2000 to 2007, that share has risen again after the crisis and the gap with the EU average is significant (16.1 per cent of temporary employment in 2016 in France against 14.2 per cent in the EU). That gap is more important for young people: among employees aged 15 to 24 , the share of temporary employment amounts to 58.6 per cent against 43.7 per cent in the EU.

Self-employment has also increased since 2007, from 10.1 per cent to 11 per cent of employment in 2016, but stands under the EU average (14 per cent in 2016). That increase largely follows the development of a specific social contributions regime in 2009 (auto-entrepreneurs), which has been very successful: in June 2016, 1.1 million 'selfmanaged' individual enterprises were registered, among which 644000 declared a positive turnover. ${ }^{23}$ Also, despite the introduction of new rules for part-time working in 2013 (24 hours minimum in the absence of a collective agreement at the sectoral level), the share of part-time employment increased from 17.2 to 18.3 per cent, less than the European average, which gained 2 percentage points over the period.

In addition to this increase in the share of atypical jobs in total employment, in line with a trend observed throughout Europe, the nature of these non-standard jobs has also changed over time. This change is particularly spectacular for temporary employment, whose uses has increased strongly since the mid-2000s, with an increasing number of contracts signed for less than one month, especially in some sectors. In the same vein of change in the nature of non-standard jobs, the new self-employed (auto-entrepreneurs) usually declare lower turnover than standard self-employed, which has resulted in a drop in average income among the self-employed (Askénazy and Erhel 2016).

The social partners have been intervening on these issues, with trade unions acting in favour of stronger regulation of atypical contracts, but generally facing employers' opposition. In practice the threshold of 24 hours a week for part-time jobs was introduced in a national agreement that was transposed into law in 2013. However, there are many limits to its implementation as the employer can depart from that minimum if the employee agrees, and branch-level collective bargaining can also modify the 24-hour threshold and introduce a lower minimum duration. In March 2015, 44 per cent of part-time employees were covered by an industry-level agreement on part-time work, generally setting a minimum part-time duration below the 24-hour threshold. As far as temporary contracts are concerned, the national agreement of 2013 introduced an additional contribution for very short-term contracts, which has been unsuccessful in decreasing their number and was replaced in 2017 with another (temporary) additional contribution. The latest (March 2018) agreement on unemployment insurance introduces compulsory negotiations on this issue at the sectoral level, setting quantitative targets, but excludes setting up a bonus-malus system based on employers' conduct.

As regards labour contracts, social dialogue has thus encountered limited success in protecting workers from atypical contracts, despite trade union efforts. However, there is relatively generous unemployment insurance coverage and replacement rate for workers on very short-term contracts. In that context, recent reforms (ordinances of September 2017) are also likely to have important consequences for the use of part-time and temporary contracts, depending on the power of workers and unions at the sectoral level; the rules for part-time and temporary contracts will now be set at the sectoral level (by sectoral collective agreements), which may increase heterogeneity across sectors. 
The second important trend towards a more flexible labour market results from successive labour law reforms introducing new rules for standard contracts. Most of these reforms involved the social partners and were prepared by social dialogue, and some of the reforms were directly based on national collective agreements (in 2008 and 2013). Some of these new rules concern dismissals (especially economic dismissals), as well as a new procedure allowing the ending of a labour contract by mutual agreement (introduced in 2008). That new scheme has been very successful: in 2017, on average 37429 contracts were terminated each month using the procedure. The September 2017 ordinances have extended this procedure from the individual to the collective level, enabling employers to conclude firm-level collective agreements, thereby authorising them to end several labour contracts at the same time, without having to draw up dismissal plans (rupture conventionnelle collective). Such agreements have to be signed by trade unions representing a majority of workers at the firm level and are controlled by the labour administration. The scheme, which some firms have already announced they will use in the coming months, may be controversial in the future.

Contrary to the apparent stability of French labour market rules in OECD job protection indexes, the labour market is characterised by a far higher degree of flexibility than is usually believed, not only for atypical employment (short-term contracts, temporary agency workers and self-employment), but also for indefinite contracts. Reforms in 2016 and 2017 increased this flexibilisation trend (which can be observed across Europe).

From the workers' point of view, the upshot is stagnating or decreasing job quality, although this, too, appears to be a European goal, according to the Laeken indicators and Europe 2020 guidelines. In France, job quality is in some instances an official trade union goal, for example, for the CFDT ('emploi de qualité pour tous', 'decent jobs for all', in 2012'; 'qualité de vie au travail', 'quality of life at work', in 2014), or the CGT ('12 exigences CGT pour investir et créer des emplois de qualité dans toute l'Europe', ['12 CGT demands for investing in and creating decent jobs throughout Europe', in 2014), in accordance with the goals formulated by the European Trade Union Confederation (ETUC) at the European level. The above indicators reflect distinct dimensions of job quality (such as wages, types of contracts, job security, working conditions, access to training, and work-family reconciliation), but some recent analyses have developed synthetic job quality indexes that allow cross-country analysis and identification of dynamics over time. Such analyses provide converging results for the French case (Erhel et al. 2013; Erhel and Guergoat-Larivière 2016; Muñoz-de-Bustillo et al. 2016; Piasna 2017). First, job quality in France stands at a relatively low level in comparison with other European countries: it is higher than in eastern and southern Europe and close to that of the United Kingdom, but lower than in Nordic and most continental countries. The dimensions that tend to be below the European average are employment quality (directly related to the issue of non-standard employment), health and safety at work, and intrinsic quality of work $^{24}$ (Muñoz-de-Bustillo et al. 2016). Cazes et al. (2015) also find that the quality of the working environment (for example, the incidence of job strain) is intermediate in France, even though earnings quality and job security (provided by unemployment insurance and social assistance schemes) are high. Second, job quality seems to have decreased during and just after the crisis, especially as regards working hours, job security and training access (Erhel et al. 2013). According to the latest results of the European Trade Union Institute (ETUI) Job Quality Index for 2015, that trend 
seems to have reversed and France showed slightly higher non-pecuniary job quality in 2015 than in 2010, which seems to have been driven by improving working conditions and by greater training participation (even if employment contracts and job security remain at the level of 2010, that is, lower than in 2005; see Piasna 2017).

In that context, what drivers might achieve better job quality? In terms of labour market policy, the current debate focuses on two issues: first, unemployment insurance will be extended to the self-employed in order to enlarge the coverage for non-standard employment; second, individual training rights should be increased by the next reform of vocational training (planned for spring 2018, see case study in section 6). However, collective bargaining will also be an important driver for job quality: at the sectoral level where collective agreements will regulate part-time and temporary employment, and at the firm level where the obligation to have some collective bargaining on quality of working life (every four years) has been maintained by the latest reforms.

\section{CASE STUDY: LIFELONG LEARNING - THE FRENCH MODEL IN A COMPARATIVE AND DYNAMIC PERSPECTIVE}

In a context of digitalisation there is evidence that higher skills will be required on the labour market, across the board. Furthermore, recent research has shown that the relationship between employment by skills and the business cycle has also changed over time. In contrast to low- and medium-skilled employment, high-skilled employment has been a-cyclical over the past ten years, so that the development of skilled employment continued even during periods of recession (Askenazy et al. 2015). All these factors show the importance of training as a source of leverage for higher and better employment in the future, and call for further investment in training, both initial and lifelong, which will be of increasing importance in the labour market. It is also an important factor in sustaining social and economic convergence in the EU in a context of heterogeneity of training systems and performance. Indeed, some important challenges remain in this field, in France and many other European countries. Social partners, often involved in the institutional system of vocational training, have an important role to play in these matters.

The goals of this case study are twofold: first, it provides comparative insights about vocational training across the EU, focusing on France; second, it summarises the main recent reform trends in France and the positions of the social partners.

\subsection{Convergence and Heterogeneity of Lifelong Training across Europe}

The heterogeneity of training systems can be viewed by means of various indicators: institutional indicators, outcome-based indicators such as participation, intensity of training, hours, expenditure per trainee and others.

Lifelong learning institutions differ in a number of ways:

- Level of implementation (national, regional or local): in France the regions are the major actor in lifelong learning. 
- The role of the social partners: this is important in France with regard to the management of training funds.

- The role of firms: this is fairly important in the traditional French model, in which firms have to devote part of their wage bill to training, or pay a specific levy to finance training funds; however, recent trends tend to emphasise the individual responsibility of workers.

- The role of the market and/or of intermediaries that orientate workers or the unemployed towards training programmes: in France the national employment agency (Pôle Emploi) plays an important role for the unemployed.

- Certification procedures and quality checks exist in almost all countries, but appear more demanding in some cases: for instance, in Denmark training programmes are required to provide evidence of the average number of hours provided, drop-out rates and employment outcomes.

As regards outcomes, the Continuing Vocational Training Survey (CVTS) provides participation rates for training financed by firms. It shows high levels of participation in the Nordic countries (except Denmark, which is just below the average), as well as in France, Belgium, Spain, Slovenia and Slovakia, but lower levels in other eastern European countries, as well as in the United Kingdom (Figures 4.4 and 4.5).

The Labour Force Survey (LFS) provides a different view, as it includes all forms of training participation (not only those taking place in the firm). The figures are not directly comparable in terms of levels, as the reference period is shorter (the last four weeks). According to this more general approach to lifelong learning (see Figure 4.6),

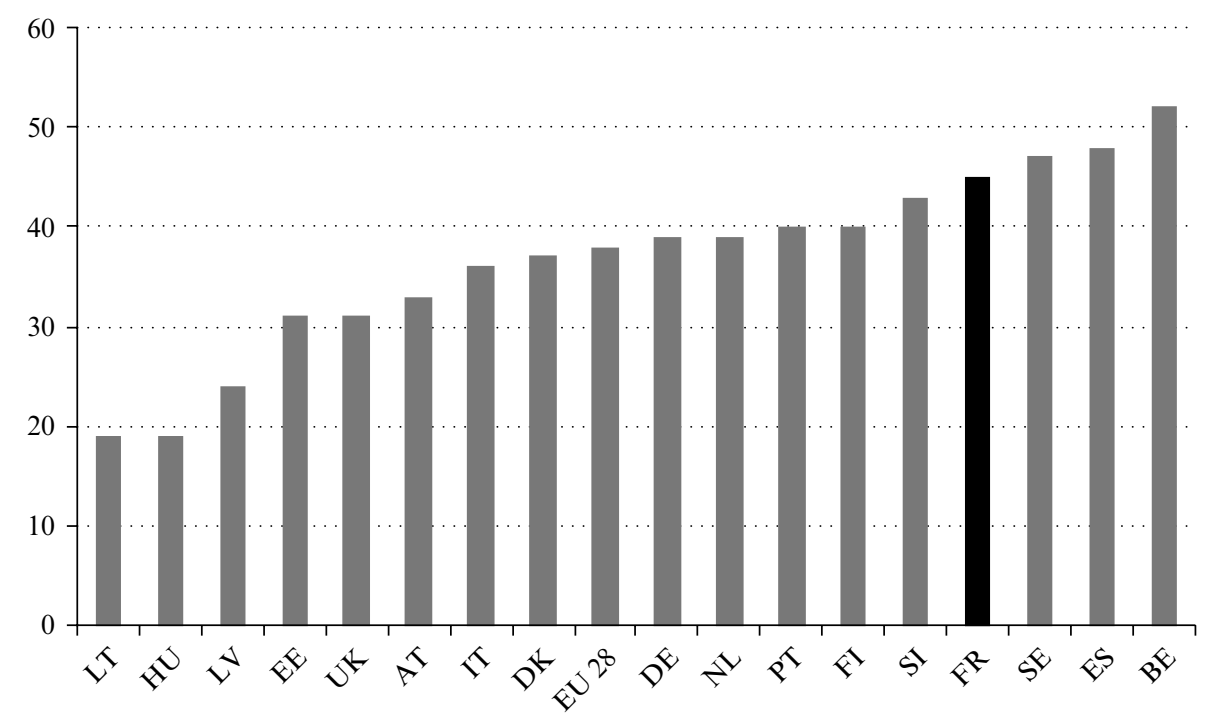

Source: CVTS.

Figure 4.4 Percentage of employees (all enterprises) participating in continuing vocational training courses in 2010, France and selected EU countries 


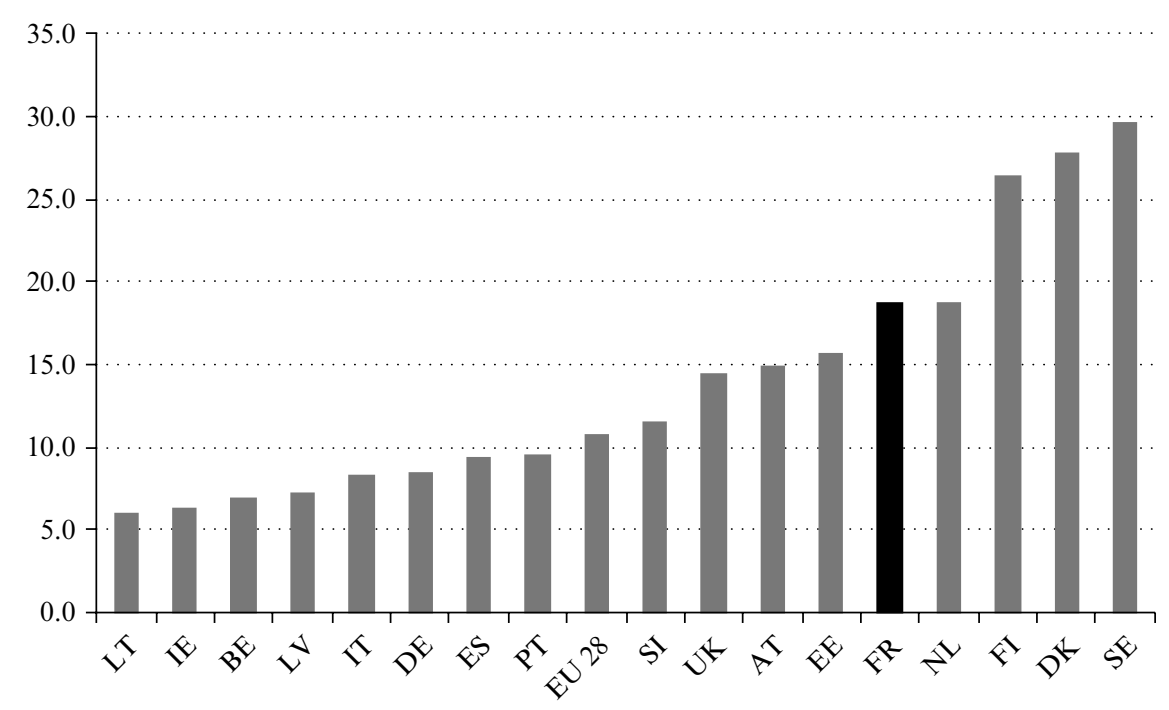

Source: LFS.

Figure 4.5 Participation rate for 24-65-year-olds in education and training (last four weeks), France and selected EU countries, 2016

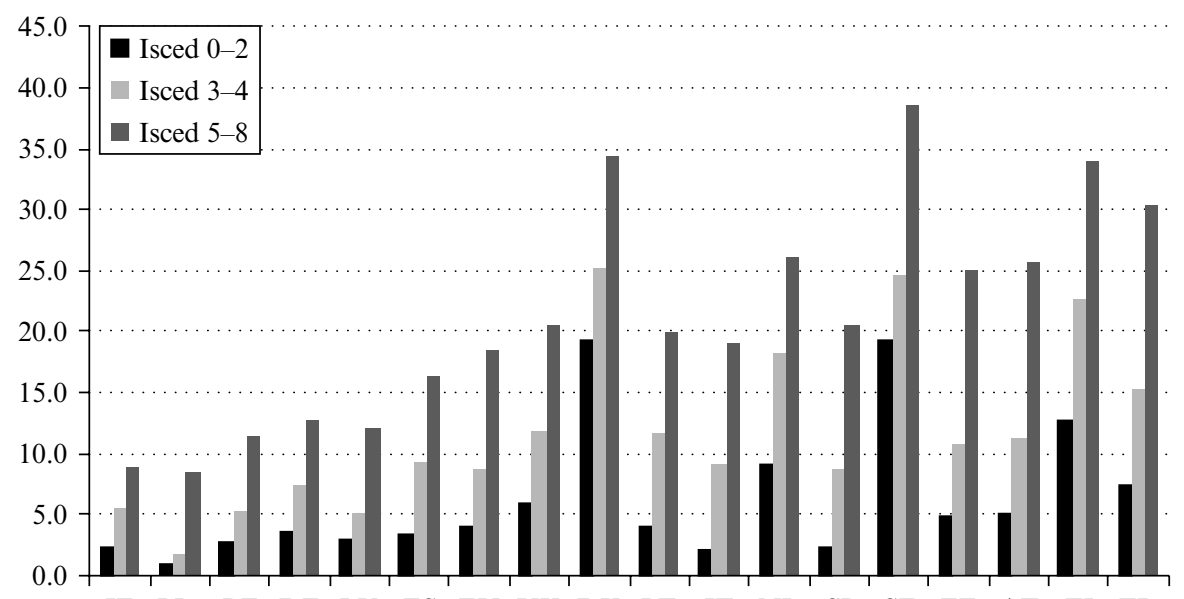

IE PL BE DE LV ES EU UK DK PT IT NL SI SE EE AT FI FR

Source: LFS, countries are ranked according to the participation gap between high and low educated.

Figure 4.6 Participation rate for 24-65-year-olds in education and training (last four weeks), by education level, France and selected EU countries, 2016 
the situation of Denmark changes radically, as it becomes the country with the highest participation rate. The participation rate is also higher in the United Kingdom with this wider perspective. Symmetrically, Belgium is among the countries with low participation rates. The position of France does not change much: firm training is an important part of adults' training, but it is not the only way to participate in lifelong learning (see below).

As to trends, training participation has increased in Europe since 2000, whatever the indicator considered, therefore showing some upward convergence. According to the LFS, the training participation rate for individuals aged 24 to 65 increased from 7.1 per cent in 2000 to 10.8 per cent in 2016. In the 17 countries for which developments can be followed over time in the various waves of the CVTS, the participation rate increased from 29 per cent in 1999 to 32 per cent in 2005 and 37 per cent in 2010. The share of firms providing training went up from 58 per cent in 1999 to 61 per cent in 2005 and 64 per cent in 2010 (Mignot 2013).

However, participation figures must be complemented by indicators of training intensity (Table 4.3), for which average hours spent in training and costs might be considered as a proxy.

France has a high level of expenditure per employee, according to CVTS firm data.

\section{Table 4.3 Intensity of training, France and selected EU countries (average cost and} hours per participant)

\begin{tabular}{lcc}
\hline & Cost of CVT courses (PPS)* & Number of hours \\
\hline AT & 1089 & 30 \\
BE & 755 & 34 \\
DE & 769 & 23 \\
DK & 779 & na \\
EE & 322 & 26 \\
ES & 353 & 20 \\
EU & 612 & 25 \\
FI & 604 & 23 \\
FR & 842 & 28 \\
IT & 355 & 23 \\
LT & 386 & 34 \\
LV & 188 & 15 \\
NL & 1111 & 35 \\
PL & 347 & 22 \\
PT & 519 & 42 \\
SE & 801 & 24 \\
SI & 559 & 37 \\
UK & 529 & 25 \\
\hline
\end{tabular}

Notes:

* PPS = Purchasing Power Standard.

$\mathrm{AT}=$ Austria, $\mathrm{BE}=$ Belgium, $\mathrm{DE}=$ Germany, $\mathrm{DK}=$ Denmark, EE = Estonia, $\mathrm{ES}=$ Spain, EU = European

Union, FI = Finland, FR = France, $\mathrm{IT}=$ Italy, $\mathrm{LT}=$ Lithuania, LV = Latvia, NL = Netherlands, PL =

Poland, $\mathrm{PT}=$ Portugal, $\mathrm{SE}=$ Sweden, $\mathrm{SI}=$ Slovenia, $\mathrm{UK}=$ United Kingdom.

Source: CVTS. 


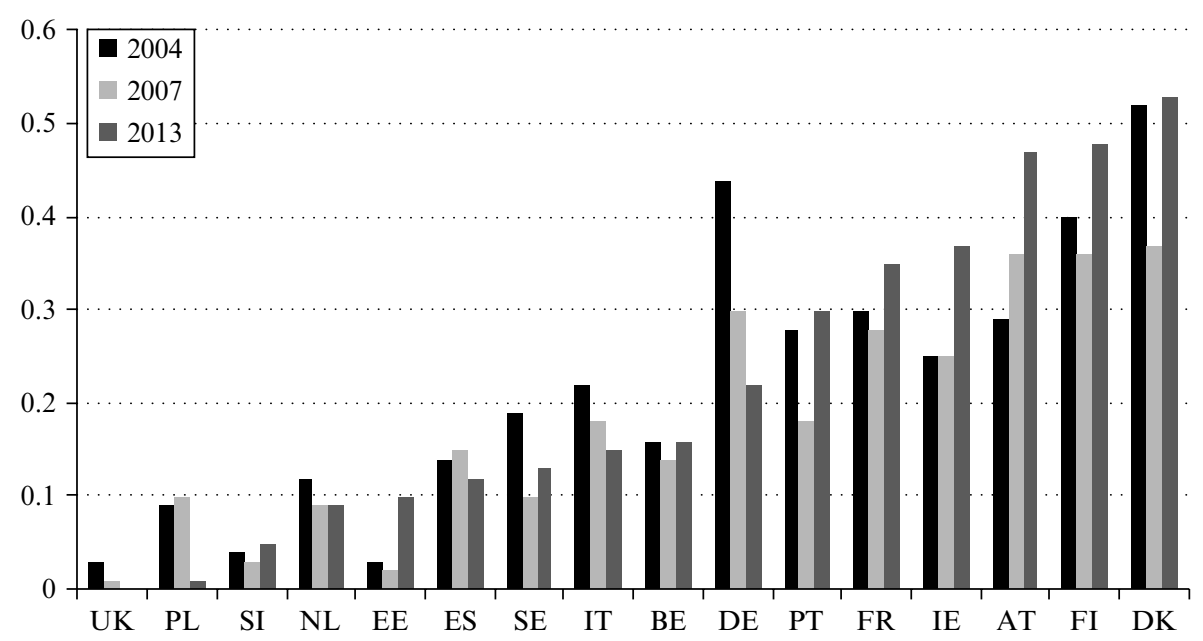

Source: OECD.

Figure 4.7 Expenditure on training for the unemployed, France and selected EU countries, 2004, 2007 and 2013 (percentage GDP)

This puts it ahead of Denmark, probably because it incentivises firms to finance training. In other continental countries (Austria, Belgium, Germany and the Netherlands), as well as Sweden and Denmark, firms make important contributions to training, in financial terms. Average hours provide a more heterogeneous picture: the average number of hours in the EU is 25, but countries such as the Netherlands, Slovenia or Portugal are characterised by longer hours in continuing vocational training (CVT) courses (over 35 hours), whereas Germany, Sweden, Spain, Italy and Latvia stand below the EU average. France is slightly above the EU average.

One of the main challenges for vocational training arises from inequalities in participation across social groups. France has the highest gap in training participation between the higher skilled and the lower skilled (Figure 4.7). The difference with Denmark, for instance, is quite marked: in the latter, participation rates are higher for all groups, and with more limited inequalities.

In addition to educational level, age also influences training participation: older workers benefit less from further training. According to a study on French data on access to training across the life course, training probability increases up to age 40, then decreases, for all skills groups. However, there are only limited opportunities for the less skilled to upgrade their skills, as they have a lower access rate to training over the whole life course (Chéron et al. 2015). More generally, recent research has highlighted the relationship between training participation and such factors as household composition, age and life course events (for example, being in a couple or having children). The probability of taking part in training is higher for men in a couple with children and for single women, and a positive impact can be seen with the start of forming a couple or divorce/separation for women. Childbirth has a negative impact on participation in training, especially for women. All of these life course factors are important when addressing changes in participation (Lignon 2017). 
Another issue with regard to lifelong learning is access to training for the unemployed. Again, heterogeneity across countries in Europe is very high. Expenditure is highest in Denmark (slightly above 0.5 per cent of GDP), whereas in the United Kingdom, spending is very limited. Between 2004 and 2013, training efforts targeted at the unemployed varied in intensity, although they are perceived as a consensus political goal. Training expenditures for the unemployed have been decreasing in several countries, including Germany, ${ }^{25}$ Italy, Spain and Sweden, whereas it has increased in France, Ireland, Austria, Finland and Denmark.

To summarise, this comparative perspective on lifelong learning shows that training for adults - especially the unemployed - is a consensus aim across countries, but heterogeneity is significant across the EU and implementation gaps remain that need to be addressed, especially inequalities. Implementation gaps are particularly important in the French case.

\subsection{What Role for Social Partners in a Context of Reforms? The French Case}

Despite the diversity of training systems, there is a common trend across the EU and the OECD towards the development of individual training rights that people may use over their life course. Such training accounts are consistent with the general flexicurity orientation that has prevailed in many European countries since the mid-2000s. Training rights also have consequences in terms of financing and institutional implementation of further training, questioning the role of actors in the system (government, regions, social partners, firms, employees or unemployed). The French case appears a good example of such transformation, which is an ongoing process as the government has announced a new reform in spring 2018.

In France, since the $1971 \mathrm{Law},{ }^{26}$ firms are compelled to spend a certain amount on training, corresponding to a percentage of the wage bill. The principle of this training levy is 'train or pay'. It is possible for firms to spend a share or the whole amount directly on their employees, or to give it to specific funds called OPCA (Organismes paritaire agréé, Joint training funds). These funds are managed by the social partners at the industrial sectoral level; they aim at mutualising funds dedicated to training and organise or co-finance some training at the sectoral level. Part of the training levy is also allocated to some regional funds (OPCACIF). ${ }^{27}$ These funds are dedicated to managing training leave (CIF), ${ }^{28}$ which enables employees to obtain a higher diploma and/or to change their job sector.

This system has been relatively efficient in leveraging funds dedicated to training. However, it remains widely criticised, for several reasons. First, to the extent that firms are the main drivers of training provision, access to training has remained unequal and reproduced observed inequality in other dimensions of the labour market and employment (education level and age). Moreover, the unemployed are at the margin of the training funds system. The administrative costs of the system are also very high for several reasons: OPCA are numerous; the quality of training is difficult to measure; and the distinction between the work dedicated to the training implementation and the work dedicated to the union is not clear enough, which was implicitly accepted as a way of financing industrial relations. A new set of reforms that started in the 2000 s has tried to respond to the main drawbacks of the system. 
The set of new reforms includes a decrease in OPCA numbers; the funds have been compelled to merge in order to reach a minimum budget, which has been raised several times by the government. The new reforms include some redirection of the money collected to a fund managed by the social partners but dedicated to the unemployed: the FPSPP (Fonds paritaire de sécurisation des parcours professionnels, Joint fund for securing labour market transitions) was created in 2014. The FPSPP is dedicated to financing training programmes at local level and it facilitates negotiations between unions and local authorities (mainly regional) on the definition of specific training programmes competing for funding.

However, the main change concerns firms' legal obligation: since 2014, all firms have had to pay a training levy of 1 per cent of their wage bill $(0.55$ per cent for firms with fewer than ten employees), whatever their internal training expenditure. These contributions (collected by the OPCAs) are mutualised and used to finance training leave, individual training accounts, training plans and so on. Every firm is responsible for training its employees and has to provide orientation interviews (in the absence of any action, firms of 50 employees and over have to pay additional hours for the individual training accounts of their employees). Also, for firms of more than 300 employees, bargaining about provisional employment management and firms' training practices is compulsory every three years.

Individual training rights (Droit individuel à la formation, DIF) were first introduced in 2003 with the DIF programme. This transfers the training initiative from the firm to the worker, but applies to only a small part of the funds collected and is subject to a number of limiting clauses that restrict the training initiative of the employee and the training rights accumulation process. In practice, implementation of the programme has not led to an increase in access to training for less-qualified workers. Owing to this, in negotiations at national level, unions have put forward another individual right to foster access to training among less-qualified workers: career counselling (Conseil en Evolution Professionnelle) has to be provided by public operators. This new right was included in the national agreement of $2013 .{ }^{29}$ More generally, these individual rights have been extended by the creation of an individual training account (Compte personnel de formation, CPF) for all employees. One important change with this reform is transferability of training rights across firms and sectors in case of job change. The other main innovation was the definition at the national level of training programmes that can be used with these individual rights and given a national certification. This certification process includes the social partners, but it is very long and has led to significant delays in the complete implementation of the reform. However, the menu of certified training available is still increasing.

Beyond the training system reforms two main trends should be noted: a generalisation of individual rights and the development of new negotiation levels that include unions. In 2016, the training account was included in a more general individual 'activity' account that also includes an account devoted to compensation ${ }^{30}$ for arduous working conditions and a civic account. ${ }^{31}$ The other important innovation is the inclusion of social partners in negotiations at regional level. In 2014 the law launched two new institutions ${ }^{32}$ aimed at developing negotiations at the regional level and including regional representatives of the social partners. The idea is clearly to enhance the unions' capacity to negotiate and organise training by adding a negotiation level - the regional - that is not in their usual mandate (Tuchszirer 2017). 
The 2018 reform confirms the trend towards the development of individual rights to training, based on the CPF. Individuals will have direct access to training programmes through an Internet portal. The management of training funds will change, as it will be the responsibility of the social security system and no longer the OPCAs. However, the social partners remain involved in the definition of training programmes at the sectoral level and through specific institutions financing apprenticeship centres and training for small firms. They will also participate in a tripartite national institution in charge of training market regulation (prices and quality).

To conclude, comparative analysis reveals substantial heterogeneity in lifelong learning policies across Europe, and the French case highlights relatively high levels of participation but important inequalities in access to training. Recent reforms have stressed the individualisation of training rights, but may not be enough to obtain better access for disadvantaged groups (especially the lower qualified).

\section{CONCLUSIONS}

French labour market and social policies have undergone significant changes since the early 2000s, generally consistent with the goals set at the European level by the Lisbon Strategy and Europe 2020. In particular, the concern for disadvantaged groups has been growing with the adoption of targets for higher employment among older workers and later retirement, improved gender equality, lower school drop-out rates or better youth integration policies, and the development of individual rights to training. At the same time, general measures have been implemented to reform labour market regulations and introduce more flexibility in labour contracts and in the collective bargaining process at firm level.

Even if the state generally took the lead, the social partners have participated in all these policy areas through social dialogue at the national level, and through decentralised bargaining in sectors and firms. They still have a prominent role in French labour market regulation, especially in the determination of wages (that have remained dynamic in France even since the crisis) and the management of social rights for workers. Indeed, they have directly contributed to maintaining high levels of protection through unemployment insurance and also to developing new rights (such as accounts and compensation for arduous work, which play an important role in a period of retirement reforms). They are also directly involved in the definition and management of lifelong learning, although some tensions might arise in relation to the implementation of the most recent institutional and financing reforms.

\section{NOTES}

1. 'Loi no. 2016-1088 du 8 août 2016 relative au travail, à la modernisation du dialogue social et à la sécurisation des parcours professionnels' ('Regulation no. 2017-1386 of 22 September 2017on firm level social and economic dialogue reorganization, favoring the implementation of trade union responsibilities'), accessed 21 December 2018 at https://www.legifrance.gouv.fr/affichTexte.do?cidTexte=JORFTEXT000032983213 \&categorieLien $=\mathrm{id}$.

2. 'Ordonnance no. 2017-1386 du 22 septembre 2017 relative à la nouvelle organisation du dialogue social 
et économique dans l'entreprise et favorisant l'exercice et la valorisation des responsabilités syndicales' ('Regulation no. 2017-1386 of 22 September 2017 on firm level social and economic dialogue reorganization, favouring the implementation of trade union responsibilities'), accessed 21 December 2018 at https:// www.legifrance.gouv.fr/eli/ordonnance/2017/9/22/MTRT1724789R/jo/texte.

3. Minimum wages, occupational classifications, private social protection, vocational training, gender equality and hard/dangerous working conditions ('arduousness').

4. 'Aujourd'hui, on a une trop grande divergence sur le plan social entre les Etats membres. Et donc ce qu'on a su faire sur le plan monétaire, sur le plan économique qui est de progressivement, en ayant une stratégie à 10 ans, faire converger des gens autour d'un corridor puis d'un point unique, en quelque sorte avant un point de référence qui faisait converger nos économies, on doit faire pareil sur le plan social, on doit définir quel est notre standard commun.' ('Today there is too much divergence on social matters between member states. So what we have been achieving for monetary affairs, obtaining progressive convergence over 10 years, we need to do the same for social issues; we have to define a common standard.') Speech by the French President at the 'Social summit for equal growth and jobs', Gothenburg, 17 November 2017, accessed 21 December 2018 at https://ue.delegfrance.org/proclamation-du-socle-europeen-des.

5. See https://www.cfdt.fr/portail/actualites/international/europe/socle-europeen-des-droits-sociaux-une-pro messe-a-tenir-srv2_573099 (accessed 21 December 2018).

6. 'Rien de pire qu'une promesse non tenue. Le socle doit se traduire maintenant en mesures concrètes sur la formation, l'apprentissage, l'accès à l'emploi des jeunes, les contrats de travail et par des investissements dans le secteur public. Cela ne se fera pas sans dialogue social, au niveau européen et dans chacun des pays.' ('There is nothing worse than a promise that is not kept. The pillar must be translated into measures for training, apprenticeship, youth employment, employment contracts and investments in the public sector. This will not happen without social dialogue, at the European level and in each country.') Accessed 21 December 2018 at http://www.cgt.fr/Socle-europeen-de-droits-sociaux-une-occasion-a-saisir.html).

7. Policies designed to fight youth unemployment and to reduce the number of NEETs, which are also an important concern in France, are not examined here because they do not directly involve the social partners. Among recent policies the Youth Guarantee programme is considered a relative success for disadvantaged young people. It is implemented by the public employment service (special services targeted at young people, called Missions Locales).

8. With this set of reforms, it increases from 37.5 years before 1993 to 43 years after the 2014 reform.

9. The 2010 reform set a progressive increase in the legal retirement age from 60 to 62 in 2018 .

10. Malus and bonus were introduced in 2003 and strengthened in 2008.

11. Two schemes were launched: in 1999 the Cessation anticipée des travailleurs de l'amiante (Early death of asbestos workers) (CAATA), which targeted especially workers exposed to asbestos, and in 2000 the Cessation d'Activité des Travailleurs Salariés (Cessation of Activity of Employed Workers) (CATS). In 2010, a new early retirement measure was introduced for workers with a recognised work-related disability (Retraite anticipée pour handicap et pénibilité).

12. The conditions of access to these schemes (career length, age of retirement) have changed over time.

13. Compte personnel de prévention à la pénibilité (Individual account for the prevention of arduousness).

14. The individual account became the Compte prévisionnel de prevention $(\mathrm{C} 2 \mathrm{P})$.

15. In 1994 and 2004, respectively.

16. Prestation partagée d'éducation de l'enfant (Shared education allowance, PréParE).

17. Loi du 27 janvier 2011 relative à la représentation équilibrée des femmes et des hommes au sein des conseils d'administration et de surveillance et à l'égalité professionnelle. Loi du 12 mars 2012 relative à l'accès à l'emploi titulaire et à l'amélioration des conditions d'emploi des agents contractuels dans la fonction publique, à la lutte contre les discriminations et portant diverses dispositions relatives à la fonction publique (Law of 27 January 2011 on men's and women's representation in boards and on gender equality at work. Law of 12 March 2012 on access to permanent employment in the public sector, with a focus on fight again discriminations).

18. Décret no. 2012-1408 du 18 décembre 2012, relatif à la mise en œuvre des obligations des entreprises pour l'égalité professionnelle entre les femmes et les hommes. Loi du 4 août 2014 pour l'égalité réelle entre les femmes et les hommes. (Decree no. 2012-1408 of 18 December 2012, on firms' obligations in respect of gender equality at work. Law of 4 August 2014 for effective equality between men and women.) September 2017 ordinances have also clarified the collective bargaining process concerning gender equality.

19. http://travail-emploi.gouv.fr/dialogue-social/egalite-professionnelle-et-salariale-femmes-hommes/article/lanegociation-collective-en-entreprise-en-faveur-de-l-egalite-professionnelle (accessed 21 December 2018).

20. Especially in 2017; see http://travail-emploi.gouv.fr/ministere/documentation-et-publications-officielles/ rapports/article/smic-rapport-du-groupe-d-experts-2017 (accessed 21 December 2018).

21. Since the July 2016 El Khomri Act, to be valid, a sector-level agreement must be signed by union representatives representing one or more organisations, accounting for at least 30 per cent of the votes, and by at least one employers' federation recognised as representative. 
22. See Cahuc and Zylberberg (2017).

23. Source: ACOSS, https://www.federation-auto-entrepreneur.fr/actualites/11-million-d-autoentrepreneursfin-juin-2016 (accessed 21 December 2018).

24. Skills, autonomy and social support.

25. In the German case this might partly be the result of the decrease in the level of unemployment after 2008 .

26. Loi no. 71-575 du 16 juillet 1971 portant organisation de la formation professionnelle continue dans le cadre de l'éducation permanente (Law no. 71-575 of 16 July 1971 on continuous training organization).

27. Organisme paritaire au titre du congé individuel de formation (Joint fund for individual training leave).

28. Congé individuel de formation (Individual training leave).

29. Accord National Interprofessionnel 2013, was passed into law in 2014 and implemented in 2015.

30. Compte prévisionnel de prevention (C2P).

31. Compte engagement citoyen (citizenship individual account, CEC).

32. The Comité paritaire interprofessionnel régional pour l'emploi et la formation (Joint regional and intersectoral committee for employment and training, COPAREF) and the (CREFOP) (Comité régional de l'emploi, de la formation et de l'orientation profesionnelle, Regional committee for employment, training and vocational orientation).

\section{REFERENCES}

Amable, B. (2003), The Diversity of Modern Capitalism, Oxford: Oxford University Press.

Askénazy, P. and C. Erhel (2016), Qualité de l'emploi et productivité, pamphlet no. 43, Ed. ENS Rue d'Ulm.

Askénazy, P., A. Bozio and C. García-Peñalosa (2013), 'Dynamique des salaires par temps de crise', Les notes du conseil d'analyse économique no. 5, April.

Askénazy, P., M. Chevalier and C. Erhel (2015), 'Okun's laws differentiated by education', Document de travail CEPREMAP no. 1514.

Barbier, J.-C. (2008), La longue marche vers l'Europe Sociale, Paris: Presses Universitaires de France.

Cahuc, P. and A. Zylberberg (2017), 'Halte à l'extension des conventions de branche', LesEchos.fr, 26 June, accessed 30 November 2018 at https://www.lesechos.fr/idees-debats/cercle/030410877994halte-a-lextension-des-conventions-de-branche-2097594.php\#yhIY0M4cHcE1smtq.99.

Caser, F. and A. Jolivet (2014), 'L'incitation à négocier en faveur des older workers. Un instrument efficace?', La revue de l'IRES, 80 (1), 27-48.

Cazes, S., A. Hijzen and A. Saint-Martin (2015), 'Measuring and assessing job quality: the OECD job quality framework', OECD Social, Employment and Migration Working Paper No. 174, OECD, Paris.

Chamkhi, A. and F. Toutlemonde (2015), 'Ségrégation professionnelle et écarts de salaires hommes femmes', Dares Analyses, November, no. 082.

Chéron, A., P. Courtioux and V. Lignon (2015), 'Maintenir la formation continue pour les older workers: Pourquoi? Comment? Combien?', Edhec Position Paper, May, Edhec Business School, Paris.

Claisse, C., C. Daniel and A. Naboulet (2011), 'Les accords collectifs d'entreprise et plans d'action en faveur de l'emploi des salariés âgés: une analyse de 116 textes', Document d'études DARES, no. 157.

Courtioux, P. and C. Erhel (2005), 'Les politiques en faveur des older workers: quelles réformes? Comparaison Allemagne, France, Royaume-Uni, Suède', Travail et Emploi, 102 (April-May), 107-18.

Direction Générale du Travail (DGT) (2018), 'Bilan de la négociation collective 2017' ('Report on collective bargaining 2017'), National Commission for Collective Bargaining, Ministry of Labour, accessed 21 December 2018 at https://travail-emploi.gouv.fr/ministere/documentation-etpublications-officielles/rapports/article/rapports-bilans-de-la-negociation-collective.

Erhel, C. and M. Guergoat-Larivière (2016), 'Innovation and job quality regimes: a joint typology for the EU', QuInnE Working Paper, WP5-2-2016.

Erhel, C. and B. Palier (2005), 'The leverage effect: the open method of coordination in France', in P. Pochet and J. Zeitlin (eds), The Open Method of Coordination in Action: The European Employment and Social Inclusion Strategies, Brussels: PIE-Peter Lang. 
Erhel, C., M. Guergoat-Larivière, J. Leschke and A. Watt (2013), 'Tendances de la qualité de l'emploi pendant la crise: une approche européenne comparative', Document de travail du CEE, no. 161-2, March.

Esping-Andersen, G. (1990), The Three Worlds of Welfare Capitalism, Cambridge: Polity Press; Princeton, NJ: Princeton University Press.

Gautier, E. (2017), 'Les salaires minima de branche en France', Revue française d'économie, 32 (2017/1), 94-136.

Guillaume, C., S. Pochic and R. Silvera (2015), 'Dans les syndicats: du volontarisme à la contrainte légale', Travail, genre et sociétés, 34 (2), 193-8.

Jolivet, A. (2011), 'Pénibilité du travail: la loi de 2010 et ses usages par les acteurs sociaux', La revue de l'IRES, 70 (3), 33-60.

Jolivet, A. and J. Thébault (2014), 'Le contrat de génération: une occasion manquée pour la transmission professionnelle?', La revue de l'IRES, 80 (1), 105-25.

Lemière, S. (ed.) (2013), 'L'accès à l'emploi des femmes: une question de politiques ...', Rapport d'une Mission sur l'emploi des Femmes, Ministère des Droits des Femmes, Paris.

Lignon, V. (2017), 'Continuing education: a family matter?', Travail et Emploi, 143 (JulySeptember) special edition, 127-58.

Mignot, J.-F. (2013), 'Formation continue des salariés en Europe: les écarts entre pays se réduisent encore', Bref CEREQ no. 312.

Ministère du Travail (2017), Bilan de la négociation collective en 2016, Paris: Ministry of Labour.

Minni, C. and J. Moschion (2010), 'Activité féminine et composition familiale depuis 1975', Dares Analyses, no. 027, May.

Muñoz-de-Bustillo, R., R. Grande and E. Fernández-Macías (2016), 'Innovation and job quality: an initial exploration', QuInnE Working Paper, WP5-1-2016.

Piasna, A. (2017), “'Bad Jobs” Recovery? European Job Quality Index 2005-2015', ETUI Working Paper No. 2017.06, European Trade Union Institute, Brussels.

Tuchszirer, C. (2017), 'Enjeux et usages de la formation professionnelle dans la sécurisation des trajectoires d'emploi: des initiatives territoriales aux réformes nationales', Document de travail CEET no. 194, September. 


\section{APPENDIX 4A.1}

Table 4A.1 Social pillar indicators: an extended approach

\begin{tabular}{|c|c|c|c|}
\hline & EU average & France & $\begin{array}{l}\text { Variation } \\
2005-15\end{array}$ \\
\hline \multicolumn{4}{|l|}{ Social Pillar (SP) } \\
\hline Early leavers & 11 & 9.2 & - \\
\hline Gender employment gap & 11.5 & 7.2 & - \\
\hline Income quintile share ratio & 5.2 & 4.3 & + \\
\hline People at risk of poverty or social exclusion & 23.7 & 17.7 & - \\
\hline $\begin{array}{l}\text { Young people not in employment, education or training } \\
\text { (NEET) }\end{array}$ & 12 & 12 & + \\
\hline Employment rate & 70.1 & 69.5 & + \\
\hline Unemployment rate & 9.4 & 10.4 & + \\
\hline Participation in labour market activation policies & & 41.2 & - \\
\hline $\begin{array}{l}\text { Real adjusted gross disposable income of households, } \\
\text { per capita in PPS* (index }=2008 \text { ) }\end{array}$ & 101.56 & 107.9 & + \\
\hline Compensation of employees per hour worked & 22.9 & 32.2 & + \\
\hline $\begin{array}{l}\text { Impact of social transfers (excluding pensions) on } \\
\text { poverty reduction }\end{array}$ & 33.72 & 43.1 & - \\
\hline Children below 3 years of age in formal childcare & 33.9 & 41.8 & + \\
\hline Self-reported unmet need for medical care & 3.2 & 1.2 & - \\
\hline Digital skills & 55 & 55 & na \\
\hline \multicolumn{4}{|l|}{ Access to the labour market } \\
\hline $\begin{array}{l}\text { Employment and activity by sex and age, annual data, } \\
\text { employment females } 20-64\end{array}$ & 64.4 & 66 & + \\
\hline $\begin{array}{l}\text { Employment and activity by sex and age, annual data, } \\
\text { employment total } 55-64\end{array}$ & 53.4 & 48.7 & + \\
\hline $\begin{array}{l}\text { Unemployment rates by sex, age and educational } \\
\text { attainment level (\%), youth unemployment total }\end{array}$ & 20.2 & 24.7 & + \\
\hline Youth unemployment ratio by sex and age, total $15-24$ & 8.4 & 9.1 & + \\
\hline \multicolumn{4}{|l|}{ Wages } \\
\hline Gender wage gap (unadjusted) & & 15.7 & na \\
\hline Median wage PPP & 27837 & 28589 & + \\
\hline Monthly minimum wage & & 1392.85 & + \\
\hline $\begin{array}{l}\text { Minimum relative to average/median wages of full-time } \\
\text { workers }\end{array}$ & & 0.61 & + \\
\hline
\end{tabular}


Table 4 A.1 (continued)

\begin{tabular}{l|c|c|c}
\hline & EU average & France & $\begin{array}{c}\text { Variation } \\
2005-15\end{array}$ \\
\hline Working time & & & \\
\hline$<20$ hours & 14.9 & 9.4 & na \\
\hline$>45$ hours & 11.4 & 9.2 & na \\
\hline $\begin{array}{l}\text { Inequalities } \\
\text { Low-wage earners as a proportion of all employees } \\
\text { (excluding apprentices) by sex, total }\end{array}$ & 17.15 & 8.81 & + \\
$\begin{array}{l}\text { Education, training and lifelong learning } \\
\text { Participation rate in education and training (last } 4 \\
\text { weeks) by sex and age, male and female, 25 t64 years of } \\
\text { age }\end{array}$ & 10.8 & 18.6 & + \\
\hline $\begin{array}{l}\text { Hours in CVT courses per participant and NACE Rev, } \\
\text { 2** 2010 }\end{array}$ & 25 & 28 & na \\
\hline $\begin{array}{l}\text { Type of contract and job quality } \\
\text { Self-employed as percentage of total employment }\end{array}$ & 14 & 11 & + \\
\hline $\begin{array}{l}\text { Temporary contracts as percentage of total employment } \\
\text { Part-time as percentage of total employment }\end{array}$ & 14.1 & 16 & + \\
\hline \begin{tabular}{l} 
In-work accidents \\
\hline Social protection
\end{tabular} & 19.7 & 18.4 & + \\
\hline $\begin{array}{l}\text { Average net replacement rates over } 60 \text { months of } \\
\text { unemployment, 2015 (overall average). Family does not } \\
\text { top-ups } 2\end{array}$ & 3 & 5.2 & na \\
\hline $\begin{array}{l}\text { Pensions } \\
\text { wet pension replacement rate, male, } 1.00 \text { of average }\end{array}$ & & & \\
\hline
\end{tabular}

Notes:

* PPS = Purchasing Power Standard.

** NACE Rev, 2 = Nomenclature statistique des Activités économiques dans la Communauté Européenne

(Statistical classification of economic activities in the European Community), second revision. 
Table 4A.2a Variables used for the PCA and clustering analysis

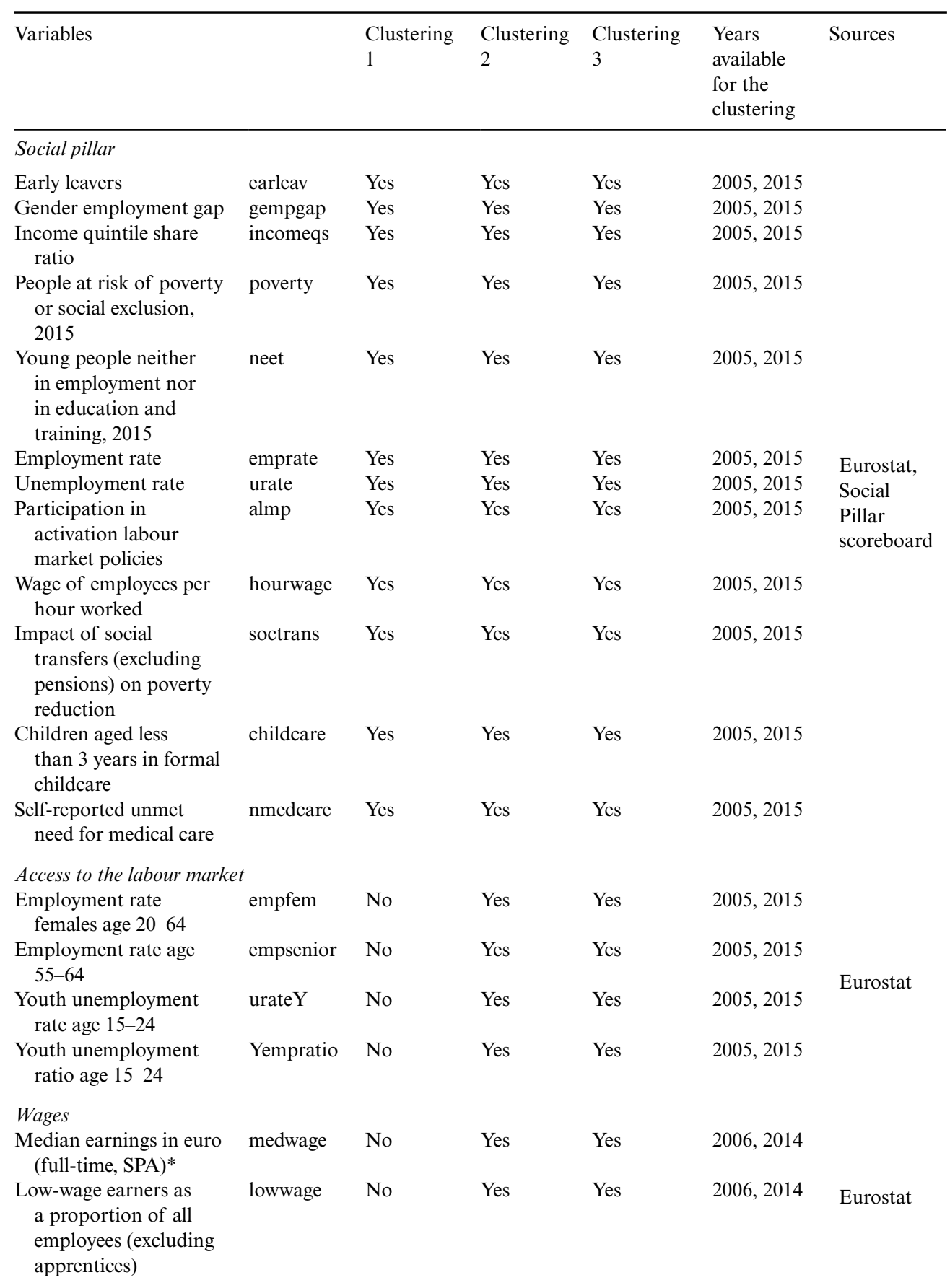


Table 4A.2a (continued)

\begin{tabular}{|c|c|c|c|c|c|c|}
\hline Variables & & $\begin{array}{l}\text { Clustering } \\
1\end{array}$ & $\begin{array}{l}\text { Clustering } \\
2\end{array}$ & $\begin{array}{l}\text { Clustering } \\
3\end{array}$ & $\begin{array}{l}\text { Years } \\
\text { available } \\
\text { for the } \\
\text { clustering }\end{array}$ & Sources \\
\hline \multicolumn{7}{|c|}{ Education, training and lifelong learning } \\
\hline $\begin{array}{l}\text { Participation rate in } \\
\text { education and } \\
\text { training (last } 4 \text { weeks) } \\
\text { age from } 25 \text { to } 64\end{array}$ & parted & No & Yes & Yes & 2005,2015 & Eurostat \\
\hline \multicolumn{7}{|c|}{ Types of contracts and job quality } \\
\hline Self-employment (1 000) & selfemp & No & Yes & Yes & 2005,2015 & \\
\hline $\begin{array}{l}\text { Temporary employees as } \\
\text { percentage of the total } \\
\text { number of employees }\end{array}$ & tempwork & No & Yes & Yes & 2005,2015 & Eurostat \\
\hline \multicolumn{7}{|c|}{ Social protection and pensions } \\
\hline $\begin{array}{l}\text { Average of net } \\
\text { replacement rates } \\
\text { over } 60 \text { months of } \\
\text { unemployment, } 2015 \\
\text { (overall average)** }\end{array}$ & rrunemp & No & Yes & No & 2015 & OECD \\
\hline $\begin{array}{l}\text { Net pension replacement } \\
\text { rate, male, } 1.00 \text { of } \\
\text { average wage }\end{array}$ & rrpension & No & Yes & No & 2016 & \\
\hline
\end{tabular}

Notes:

* Industry, construction and services (except public administration, defence, compulsory social security); SPA $=$ Standard de Pouvoir d'Achat (Purchasing Power Standard).

** Family does not qualify for cash housing assistance or social assistance 'top ups'. 


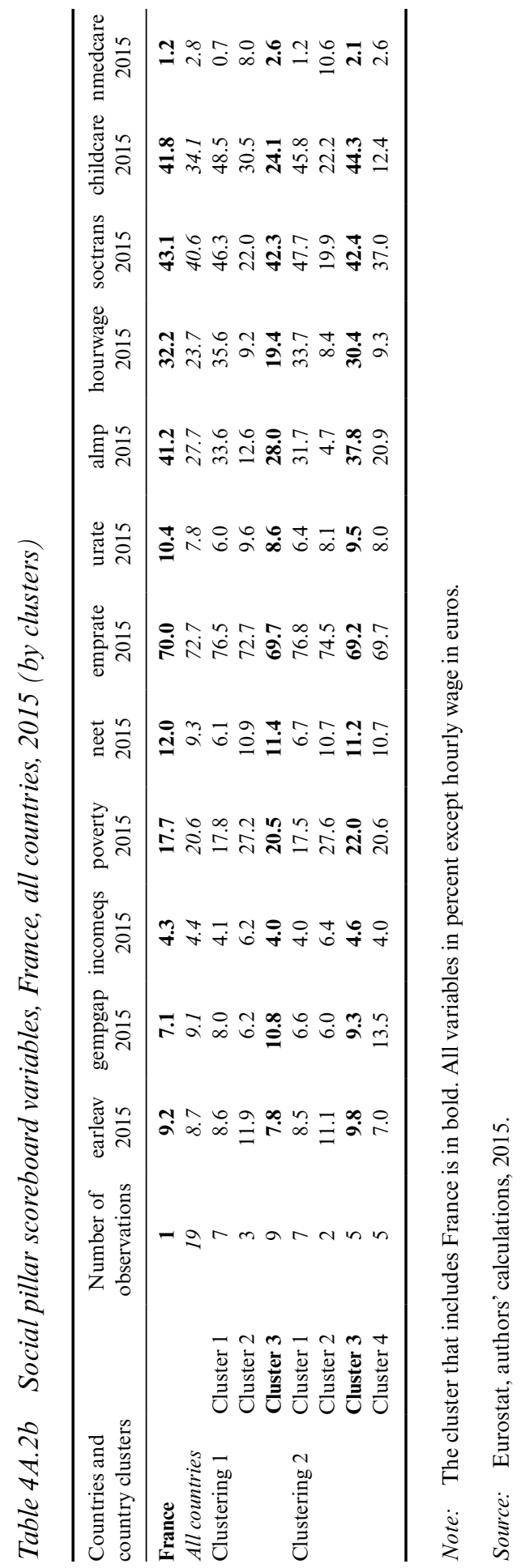




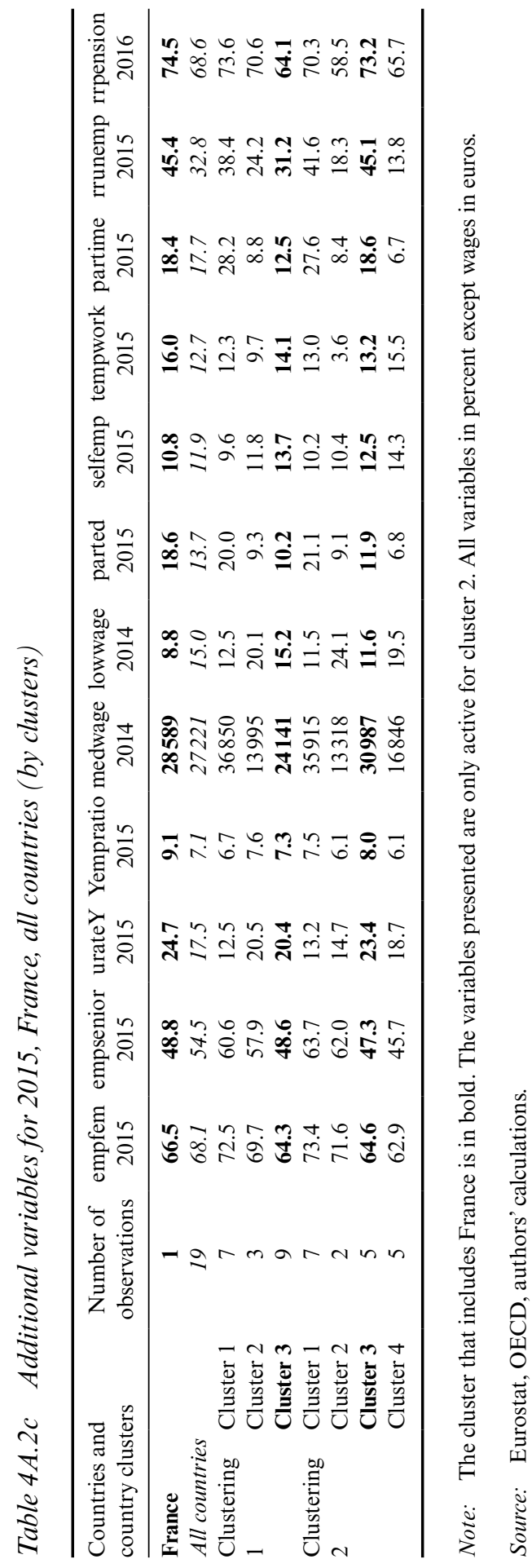




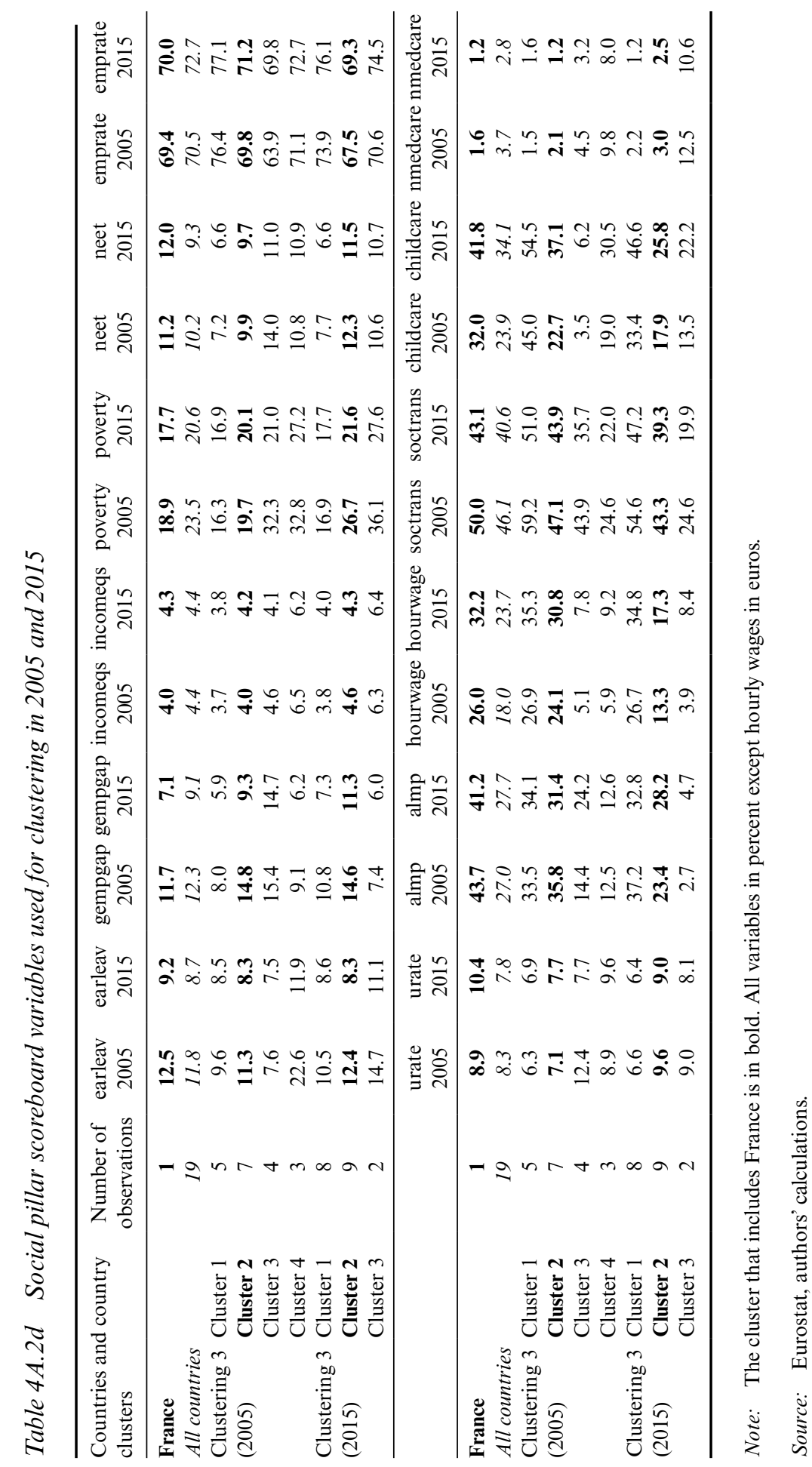




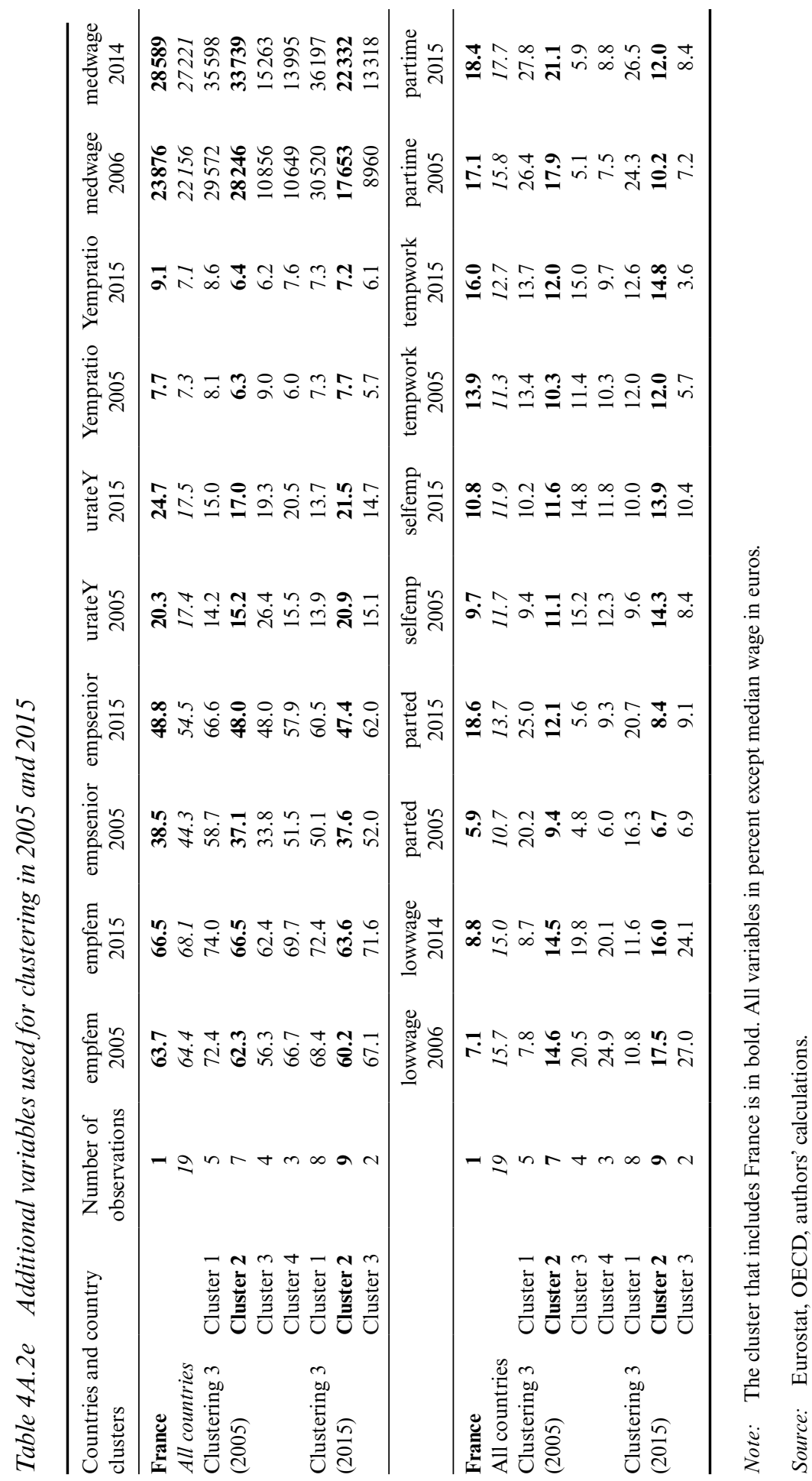

